\title{
Discovery and Pharmacological Characterization of Novel Quinazoline-based PI3K delta-selective Inhibitors
}

Klemens Hoegenauer*, Nicolas Soldermann*, Frédéric Stauffer, Pascal Furet, Nadege Graveleau, Alexander B. Smith, Christina Hebach, Gregory J. Hollingworth, Ian Lewis, Sascha Gutmann, Gabriele Rummel, Mark Knapp, Romain M. Wolf, Joachim Blanz, Roland Feifel, Christoph Burkhart and Frédéric Zécri

\section{SUPPORTING INFORMATION}




\section{Content}

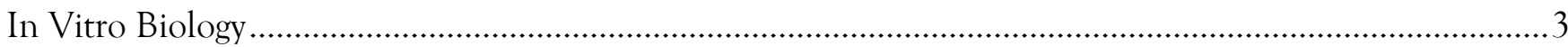

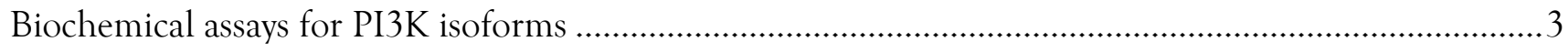

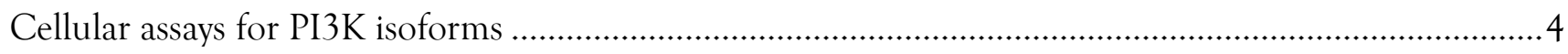

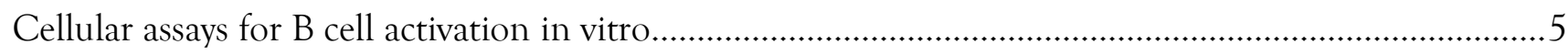

Rat B cell activation in diluted whole blood (CD86) . ........................................................................

Human B cell activation in diluted whole blood (pAkt). .....................................................................6

Human B cell activation in diluted whole blood (CD69, CD86), .............................................................

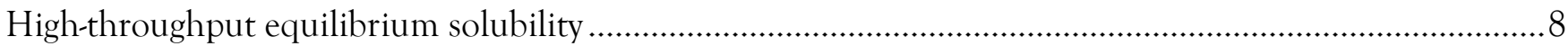

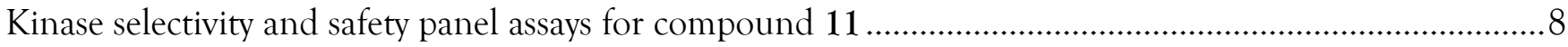

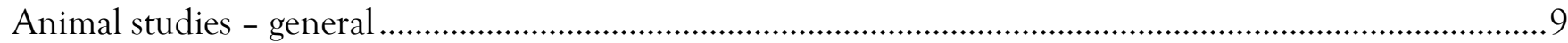

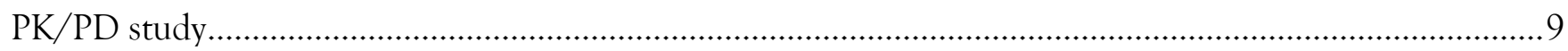

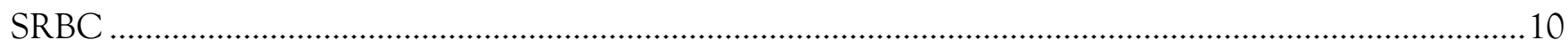

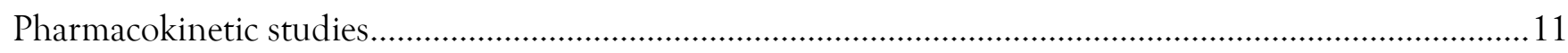

In vivo pharmacokinetic studies in rats..............................................................................11

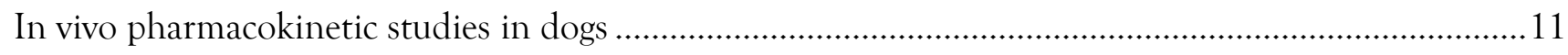

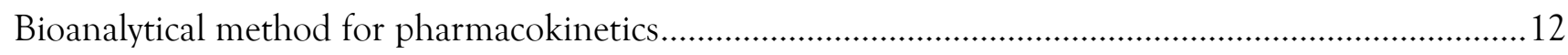

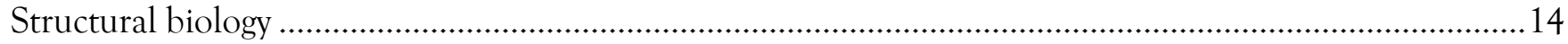

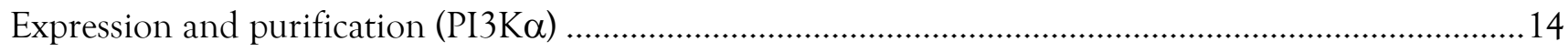

Co-crystallization of the PI3Ka/compound 11 complex and structure refinement ................................15

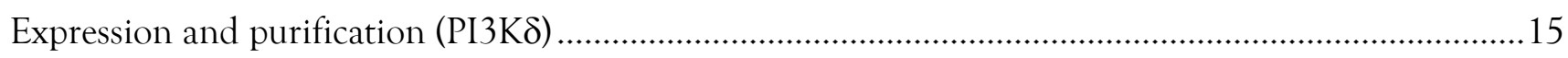

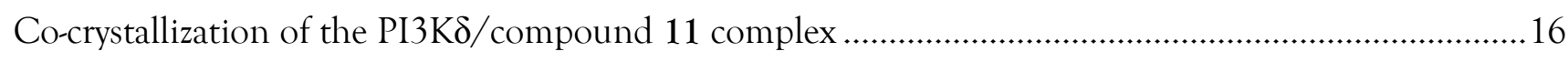

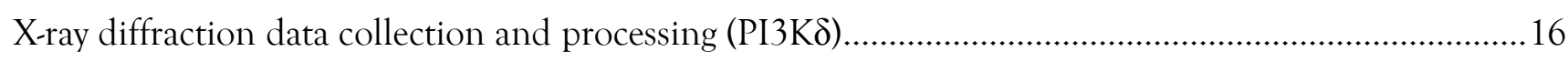

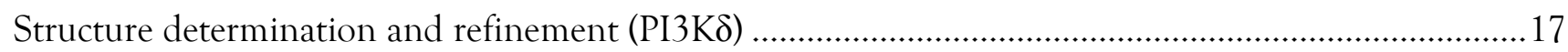

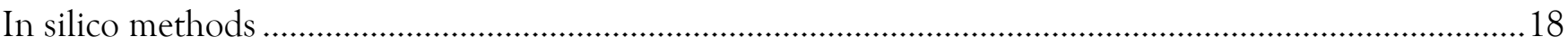

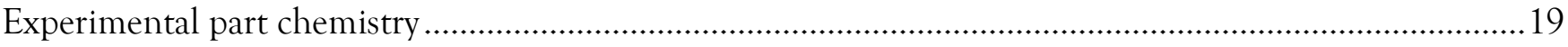

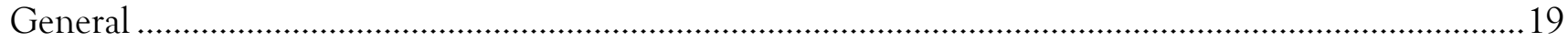

General synthetic sequence towards 4,6-diaryl quinazolines .................................................................20

Synthesis and full characterization of 5-(4-(3-(4-acetylpiperazine-1-carbonyl)phenyl)quinazolin-6-yl)-2-

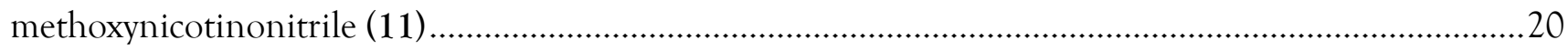

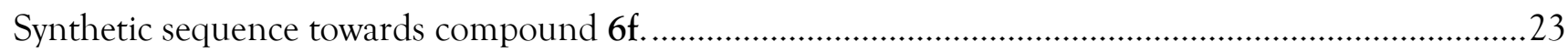

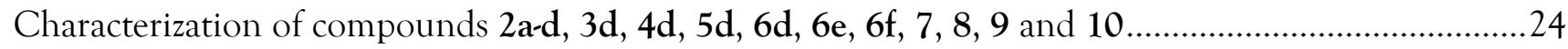

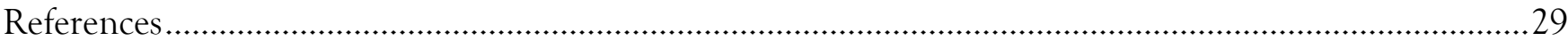




\section{$\underline{\text { In Vitro Biology }}$}

\section{Biochemical assays for PI3K isoforms}

\section{KinaseGlo format}

The inhibitory kinase activities on PI3K $\alpha$ and PI3K $\beta$ were determined using phosphatidyl inositol (PI) as substrate in n-Octyl-Glucoside (OG) using a luminescence assays based on ATP consumption (KinaseGlo). Some $50 \mathrm{nl}$ of compound dilutions were dispensed onto black 384-well plates (Greiner Cat. No.784076). L- $\alpha$-phosphatidylinositol (PI), provided as $10 \mathrm{mg} / \mathrm{ml}$ solution in methanol, was transferred into a glass tube and dried under nitrogen beam. It was then resuspended in 3\% (v/v) Octylglucoside by vortexing and stored at $4^{\circ} \mathrm{C}$. Some $4.5 \mu \mathrm{l}$ of a mix of PI/OG with $10 \mathrm{nM} \mathrm{PI} 3 \mathrm{~K} \alpha$ or $0.75 \mu \mathrm{g} / \mathrm{ml} \mathrm{PI} 3 \mathrm{~K} \beta$ was added. The kinase reactions were started by addition of $4.5 \mu \mathrm{l}$ of ATP-mix containing in a final volume of $9 \mu$ the following: $10 \mathrm{mM}$ TRIS-HCl pH 7.5, $3 \mathrm{mM} \mathrm{MgCl}_{2}$ or $3 \mathrm{mM} \mathrm{MnCl}_{2}, 50 \mathrm{mM} \mathrm{NaCl}, 0.05 \%$ CHAPS, $1 \mathrm{~m} \mathrm{M}$ DTT and $1 \mu \mathrm{M}$ ATP. The reactions were carried out at room temperature for either 30 or 60 minutes (PI3K $\alpha$ or PI3K $\beta$, respectively) stopped with $9 \mu$ of Kinase Glo and plates were read 10 minutes later in a Synergy 2 reader using an integration time of 0.1 seconds per well. To generate the $100 \%$ inhibition of the kinase reaction $\mathrm{PI} / \mathrm{OG}$ in kinase buffer without addition of recombinant kinases was used while the $0 \%$ inhibition was given by the solvent vehicle $(90 \% \mathrm{v} / \mathrm{v}) \mathrm{DMSO})$ in water in the presence of recombinant kinases.

\section{ADAPTA format}

The kinase assay format used for measuring the activity on PI3K $\gamma$ and PI3K $\delta$ is non-radioactive and monitors the formation of ADP TR-FRET (ADAPTA).

Some $50 \mathrm{nl}$ of compound dilutions were dispensed onto white 384-well small volume polystyrene plates. Then, $4.5 \mu \mathrm{l}$ of PI3K substrate PI followed by $4.5 \mu \mathrm{l}$ of ATP (final assay volume $9 \mu \mathrm{L}$ ) are incubated at RT. The standard reaction buffer for the Adapta ${ }^{\text {TM }}$ TR-FRET assay contained $10 \mathrm{mM}$ Tris-HCl pH 7.5, 3 mM $\mathrm{MgCl}_{2}, 50 \mathrm{mM} \mathrm{NaCl}, 1 \mathrm{mM}$ DTT, and $0.05 \%$ (v/v) CHAPS. Reactions were stopped with $4.5 \mu \mathrm{l}$ of a mixture of EDTA containing the Eu-labeled anti-ADP antibody and the Alexa Fluor ${ }^{\circledR}$ 647-labeled ADP tracer in TR-FRET dilution buffer. Plates are read 30 to 60 minutes (PI3K $\gamma$ or PI3K $\delta$, respectively) later in a Synergy 2 reader using an integration time of 0.4 seconds and a delay of 0.05 seconds. Control for the $100 \%$ inhibition of the kinase reaction was performed by replacing the PI3K by the standard reaction buffer. The control for the $0 \%$ inhibition was given by the solvent vehicle of the compounds (90\% DMSO in $\mathrm{H}_{2} \mathrm{O}$ ).

$\mathrm{IC}_{50}$ values obtained via KinaseGlo and ADAPTA values have been shown to be equivalent/comparable.

\section{$\underline{\text { Radiometric format }}$}

The radiometric protein kinase assay (33PanQinase ${ }^{\circledR}$ Activity Assay)was performed in 96-well FlashPlatesTM from Perkin Elmer (Boston, MA, USA) in a $50 \mu$ l reaction volume. The reaction cocktail was pipetted in 4 steps in the following order:

- $10 \mu \mathrm{l}$ of non-radioactive ATP solution (in $\mathrm{H} 2 \mathrm{O}$ )

- $25 \mu$ of assay buffer/ [ $\gamma$-33P]-ATP mixture

- $5 \mu \mathrm{l}$ of test sample in $10 \%$ DMSO

- $10 \mu \mathrm{l}$ of enzyme/substrate mixture 
The assay contained $70 \mathrm{mM}$ HEPES-NaOH pH 7.5, $3 \mathrm{mM} \mathrm{MgCl}$, $3 \mathrm{mM} \mathrm{MnCl} 2,3 \mu \mathrm{M}$ Naorthovanadate, $1.2 \mathrm{mM}$ DTT, $1.0 \mu \mathrm{M}$ ATP, [ $\gamma$-33P]-ATP (approx. 8 x $1005 \mathrm{cpm}$ per well), $2.4 \mathrm{nM}$ protein kinase, and $20 \mu \mathrm{g} / \mathrm{ml}$ substrate (casein).

All protein kinases provided by ProQinase were expressed in Sf9 insect cells or in E.coli as recombinant GST-fusion proteins or His-tagged proteins, either as full-length or enzymatically active fragments. All kinases were produced from human cDNAs. Kinases were purified by either GSH-affinity chromatography or immobilized-metal affinity chromotography. Affinity tags were removed from a number of kinases during purification. The purity of the protein kinases was examined by SDS-PAGE/Coomassie staining, the identity was checked by mass spectroscopy.

The reaction cocktails were incubated at $30{ }^{\circ} \mathrm{C}$ for 60 minutes. The reaction was stopped with $50 \mu l$ of 2 $\%(\mathrm{v} / \mathrm{v}) \mathrm{H}_{3} \mathrm{PO}_{4}$, plates were aspirated and washed two times with $200 \mu \mathrm{l} 0.9 \%(\mathrm{w} / \mathrm{v}) \mathrm{NaCl}$. Kinase activity dependent transfer of 33Pi (counting of "cpm") was determined with a microplate scintillation counter (Microbeta. Wallac).

All assays were performed with a BeckmanCoulter Biomek 2000/SL robotic system.

For each kinase, the median value of the cpm of three wells with complete reaction cocktails, but without kinase, was defined as "low control" $(n=3)$. This value reflects unspecific binding of radioactivity to the plate in the absence of protein kinase but in the presence of the substrate. Additionally, for each kinase the median value of the cpm of three other wells with the complete reaction cocktail, but without any compound, was taken as the "high control", i.e. full activity in the absence of any inhibitor $(n=3)$. The difference between high and low control was taken as $100 \%$ activity for each kinase.

As part of the data evaluation the low control of each row of a particular plate was subtracted from the high control value as well as from their corresponding 10 "compound values". The residual activity (in \%) for each well of each row of a particular plate was calculated by using the following formula:

Res. Activity $(\%)=100$ X [(cpm of compound - low control) / (high control - low control)]

Since 10 distinct concentrations of each test compound were tested against each kinase, the evaluation of the raw data resulted in 10 values for residual activities per kinase. Based on each 10 corresponding residual activities, IC $_{50}$ values were calculated using Prism 5.04 for Windows (Graphpad, San Diego, California, USA; www.graphpad.com). The mathematical model used was "Sigmoidal response (variable slope)" with parameters "top" fixed at 100\% and "bottom" at $0 \%$.

\section{Cellular assays for PI3K isoforms}

Rat-1 fibroblast cells stably overexpressing a myristoylated form of the catalytic subunit of human PI3K $\alpha$, $\beta$ or $\delta$ were plated in 384-well plates at a density of 7500,6200 , or 4000 cells (PI3K $\alpha, \beta$ and $\delta$, respectively) in $30 \mu \mathrm{l}$ complete growth medium (Dulbecco's modified Eagle's medium (DMEM high glucose) supplemented with 10\% (v/v) fetal bovine serum, 1\% (v/v) MEM non-essential amino acids, 10 mM HEPES, $2 \mathrm{mM}$ L-glutamine, $10 \mu \mathrm{g} / \mathrm{ml}$ puromycin and $1 \%$ (v/v) Penicillin/Streptomycin) and were incubated at 37\%C / 5\% $\mathrm{CO}_{2} / 95 \%$ humidity for 24 hours. Compounds were diluted in 384-well plates to obtain 8-point serial dilutions in 90\% DMSO, as well as 4 reference compounds plus 16 high controls and 16 low (inhibited) controls. Pre-dilution plates were prepared by dispensing pipetting $250 \mathrm{nl}$ of compound solutions into 384-well polypropylen plates using a Hummingwell nanoliter dispensor. Compounds were pre-diluted by the addition of $49.75 \mu \mathrm{l}$ complete growth medium. $10 \mu \mathrm{l}$ of pre-diluted compound solution were transferred to the cell plate using a 384-well pipettor, resulting in a final DMSO concentration 
of $0.11 \%$. Cells were incubated for $1 \mathrm{~h}$ at 37\%C / 5\%CO2/95\% humidity. The supernatant was removed, the cells were lysed in $20 \mu \mathrm{l}$ of lysis buffer for AlphaScreen ${ }^{\circledR}$ SureFire ${ }^{\circledR}$ detection.

For detection of p-AKT(Ser473), the SureFire ${ }^{\circledR}$ p-Akt 1/2 (Ser473) Assay Kit (PerkinElmer, U.S.A) was used. Some $5 \mu \mathrm{l}$ of cell lysate was transferred to 384-well low volume Proxiplates for detection using a 384well pipettor. Addition of AlphaScreen ${ }^{\circledR}$ SureFire ${ }^{\circledR}$ reagents was done according to the manufacturer's protocol. First, $5 \mu \mathrm{l}$ of reaction buffer plus activation buffer mix containing AlphaScreen ${ }^{\circledR}$ acceptor beads was added, the plate was sealed, and incubated on a plate shaker for 2 hours at room temperature. Second, $2 \mu$ of dilution buffer containing AlphaScreen ${ }^{\circledR}$ donor beads was added, and the plate was incubated on plate shaker as above for a further 2 hours. The plate was read on an AlphaScreen ${ }^{\circledR}$ compatible plate reader, using standard AlphaScreen ${ }^{\circledR}$ settings.

\section{Cellular assays for $\mathrm{B}$ cell activation in vitro}

Mouse B cell activation (CD86 expression) and proliferation after B cell receptor stimulation.

Compound 11 was first dissolved and diluted in DMSO followed by a 1:50 dilution in medium. Splenocytes from Balb/c mice were isolated, resuspended and transfered to 96 well plates $(200 \mu \mathrm{l} /$ well). The diluted compound or solvent were added to the plates $(25 \mu \mathrm{l})$ and incubated at $37{ }^{\circ} \mathrm{C}$ for 1 hour. Then the cultures were stimulated with $25 \mu \mathrm{l}$ anti-IgM mAb/well (final concentration $30 \mu \mathrm{g} / \mathrm{ml}$ ) for 24 hours at 37 ${ }^{\circ} \mathrm{C}$ and stained with anti-mouse CD86-FITC and anti-mouse CD19-PerCP (2 $\mu$ l of each antibody/well, both Becton Dickinson). CD86 expression on CD19 positive B cells was quantified by flow cytometry. Based on the reduction of $\mathrm{CD} 86$ expression $\mathrm{IC}_{50}$ values were determined.

To assess effects on proliferation, murine $\mathrm{B}$ cells were stimulated via the B cell receptor by anti-IgM antibody in the presence of titrated amounts of compound and proliferation was assessed by incorporation of radioactive ${ }^{3} \mathrm{H}$-Thymidine over the last 16 hours of a 88 hour incubation period as described (Julius et al 1984).

\section{Rat B cell activation in diluted whole blood (CD86).}

For assessing effects on B cell activation upon surface B cell receptor stimulation, heparinized blood was pre-diluted to $50 \%$ with medium. Then, $180.5 \mu$ pre-diluted blood was spiked with $9.5 \mu \mathrm{l}$ of pre-diluted compound 11 in 96 well U-bottomed microtiter plates (Nunc) resulting in a 2-fold serial dilution with a concentration range from 50 to $0.008 \mu \mathrm{M}$. Control wells were pretreated with DMSO to obtain a final concentration of $0.5 \%$ DMSO. Cultures were set up in duplicates, mixed well by agitation on a plate shaker, pipetting up and down and agitated on the plate shaker again. Cultures were incubated at $37^{\circ} \mathrm{C}$, $5 \% \mathrm{CO}_{2}$ for $1 \mathrm{hr}$. Then $10 \mu \mathrm{l}$ of anti-rat IgM/rIL-4 at a final concentration of anti-rat IgM of $50 \mu \mathrm{g} / \mathrm{ml}$ and rIL-4 of $10 \mathrm{ng} / \mathrm{ml}$ was added. Control samples were left unstimulated. Samples were mixed thoroughly and incubated for 24 hours at $37^{\circ} \mathrm{C}, 5 \% \mathrm{CO}_{2}$. After incubation, $15 \mu \mathrm{l}$ of a $25 \mathrm{mM}$ EDTA solution was added per well and shaken for 15 min to detach adherent cells.

Samples were then stained with PE-Cy5-labeled anti-ratCD45RA (Becton Dickinson) to allow gating on B cells in FACS analysis. In addition, samples were stained with PE-labeled anti-rat CD86 (Becton Dickinson). 
All staining procedures were performed at room temperature for $30 \mathrm{~min}$ in the dark. After incubation, samples were transferred to 96-deep well V-bottomed microtiter plates (Corning) containing $2 \mathrm{ml} /$ well of 1x BD Lysing Solution (Becton Dickinson). After lysis of erythrocytes samples were washed with $2 \mathrm{ml}$ of CellWASH (Becton Dickinson). Data was acquired on an LSRII or FACScalibur flow cytometer (BD Biosciences) using Cellquest Plus or DIVA (version 6.1.1) software, respectively. Lymphocytes were gated in the FSC/SSC dot blot according to size and granularity and further analyzed for expression of CD45RA and activation markers. Data were calculated from dot blots or histograms as percentage of cells positively stained for activation markers within the CD45RA+ population.

Rat B cell activation in diluted whole blood (pAkt). For assessment of the in vitro effects of compound 11 on intracellular activation marker pAkt, heparinized blood was prediluted to $50 \%$ with medium. Then, $180 \mu \mathrm{l}$ prediluted blood was spiked with $10 \mu \mathrm{l}$ of pre-diluted compound 11 in $5 \mathrm{ml}$ U-bottom tubes (Becton Dickinson) resulting in a dilution with a concentration range from $16666 \mathrm{nM}$ to $0.8 \mathrm{nM}$. Control wells were pretreated with DMSO to obtain a final concentration of $0.17 \%$ DMSO. Samples were set up in duplicates, mixed well by agitation on a vortexer (3 times $1 \mathrm{sec}$, speed 1800). Samples were incubated at $37^{\circ} \mathrm{C}$ in the water bath for 1.5 hours. $10 \mu \mathrm{l}$ of diluted goat anti-rat IgM antibody (Serotec) and $10 \mu \mathrm{l}$ of diluted rIL-4 (Becton Dickinson) was added, mixed (3 times 1 sec, speed 1800) and incubated for 10 minutes at $37{ }^{\circ} \mathrm{C}$ in the water bath. After incubation, $2 \mathrm{ml}$ of pre-warmed $\left(37{ }^{\circ} \mathrm{C}\right.$ in water bath) $\mathrm{BD}$ Phosflow Lyse/Fix buffer (Becton Dickinson) was added per tube and shaken for 3 seconds on a vortexer and incubated for 20 minutes at $37^{\circ} \mathrm{C}$ in the water bath. Samples were centrifuged at $400 \mathrm{~g}$ for 5 minutes. After centrifugation $2 \mathrm{ml}$ of BD Phosflow Perm/wash buffer I (Becton Dickinson) was added per tube and incubated at room temperature in the dark for 10 minutes. After centrifugation at $400 \mathrm{~g}$ for 5 minutes the pellets were washed with $2 \mathrm{ml}$ of BD Phosflow Perm/wash buffer I and again centrifuged at $400 \mathrm{~g}$ for 5 minutes.

Samples were stained with PE-labeled anti-rat IgM, (Becton Dickinson) to allow gating on B cells in FACS analysis. In addition, samples were stained with Alexa647 conjugated anti-pAkt (Ser473; Becton Dickinson).

Staining procedures were performed in BD Phosflow Perm/wash buffer I at RT for 30 min in the dark. After incubation, samples were washed with $2 \mathrm{ml}$ of 1xBD Phosflow Perm/wash buffer I and centrifuged at $400 \mathrm{~g}$ for 5 minutes and the pellets were resuspended in $300 \mu \mathrm{l}$ BD Stain Buffer (Becton Dickinson). Samples were kept on ice until data were acquired on an LSRII flow cytometer (BD Biosciences) using DIVA (version 6.1.2) software. Lymphocytes were gated in the FSC/SSC dot blot according to size and granularity and further analyzed for expression of IgM and phosphorylation of Akt. Data were calculated from dot blots or histograms as percentage of cells positively stained for Akt-phosphorylation within the IgM+ population

\section{Human B cell activation in diluted whole blood (pAkt).}

For assessment of the in vitro effects of compound 11 on intracellular pAkt, $180 \mu$ l heparinized blood was spiked with $10 \mu \mathrm{l}$ of pre-diluted compound 11 in $5 \mathrm{ml}$ U-bottom tubes (Becton Dickinson) resulting in a dilution with a concentration range from $16666 \mathrm{nM}$ to $0.8 \mathrm{nM}$. Control samples were pretreated with DMSO to obtain a final concentration of $0.17 \%$ DMSO. Samples were set up in duplicates, mixed well by agitation on a vortex (3 times $1 \mathrm{sec}$, speed 1800). Samples were incubated at $37{ }^{\circ} \mathrm{C}$ in the water bath for $1.5 \mathrm{hr}$. Then, goat anti-human IgM antibody (Southern Biotech) in a volume of $10 \mu \mathrm{l}$ was added, mixed (3 times $1 \mathrm{sec}$, speed 1800) and incubated for $20 \mathrm{~min}$ at $37^{\circ} \mathrm{C}$ in the water bath. After incubation, $2 \mathrm{ml}$ of 
pre-warmed $\left(37^{\circ} \mathrm{C}\right.$ in water bath) BD Phosflow Lyse/Fix buffer (Becton Dickinson) was added per tube and shaken for 3 seconds on a vortexer and incubated for $20 \mathrm{~min}$ at $37^{\circ} \mathrm{C}$ in the water bath. Samples were centrifuged at $400 \mathrm{~g}$ for $5 \mathrm{~min}$. After centrifugation $2 \mathrm{ml}$ of BD Phosflow Perm/wash buffer I (Becton Dickinson) was added per tube and incubated at room temperature in the dark for $10 \mathrm{~min}$. After centrifugation at $400 \mathrm{~g}$ for $5 \mathrm{~min}$ the pellets were washed with $2 \mathrm{ml}$ of BD Phosflow Perm/wash buffer I and again centrifuged at $400 \mathrm{~g}$ for $5 \mathrm{~min}$. Supernatants were discarded and the samples were stained with anti-hu CD20 (Alexa488-labeled anti-huCD20, Becton Dickinson) to allow gating on B cells in the cytometric analysis. In addition, samples were stained with Alexa647 conjugated anti-human pAkt (Ser473; Becton Dickinson).

Staining procedures were performed in BD Phosflow Perm/wash buffer I at RT for 30 min in the dark. After incubation, samples were washed with $2 \mathrm{ml}$ of BD Phosflow Perm/wash buffer I and centrifuged at $400 \mathrm{~g}$ for 5 minutes and the pellets were resuspended in $300 \mu \mathrm{l}$ BD Stain Buffer (Becton Dickinson). Samples were kept on ice until data were acquired on an LSRII flow cytometer (BD Biosciences) using DIVA (version 6.1.2) software. Lymphocytes were gated in the FSC/SSC dot blot according to size and granularity and further analyzed for expression of CD20 and phosphorylation of Akt. Data were calculated from dot blots or histograms as percentage of cells positively stained for Akt-phosphorylation within the CD20+ population.

\section{Human B cell activation in diluted whole blood (CD69, CD86).}

For assessment of the in vitro effects of compound 11 on B cell surface activation marker, $180.5 \mu$ heparinised whole blood was spiked with $9.5 \mu$ of pre-diluted compound 11 in 96 well U-bottomed microtiter plates (Nunc) resulting in a 2 -fold serial dilution with a concentration range from 50 to $0.008 \mu \mathrm{M}$. Control wells were pretreated with DMSO to obtain a final concentration of $0.5 \%$ DMSO. Cultures were set up in duplicates, mixed well by agitation on a plate shaker, pipetting up and down and agitated on the plate shaker again. Cultures were incubated at $37{ }^{\circ} \mathrm{C}, 5 \% \mathrm{CO}_{2}$ for $1 \mathrm{hr}$. Then $10 \mu \mathrm{l}$ stimulus solution as described and mixed as above and cultures were incubated at $37^{\circ} \mathrm{C}, 5 \% \mathrm{CO}_{2}$ for a further 24 h. Following incubation, cell aggregates were broken up by addition of $15 \mu \mathrm{l} /$ well of a $25 \mathrm{mM}$ EDTA solution, $\mathrm{pH} 7.4$, to the cultures. Samples were mixed thoroughly by agitation on a plate shaker for $15 \mathrm{~min}$. Cells were stained by addition of $25 \mu \mathrm{l}$ of a mixture of fluorescent labelled antibodies, mixing on a plate shaker and incubation for $30 \mathrm{~min}$ in the dark at room temperature. Samples were stained with anti-huCD19-APC (Becton Dickinson) to allow gating on B cells in FACS analysis. In addition, samples were stained with anti-huCD69-PE-Cy7 and anti-huCD86-PE-Cy5 (both Becton Dickinson).

After staining, samples were transferred to 96-deep well V-bottomed microtiter plates, (Corning) containing $2 \mathrm{ml} /$ well of 1x BD Lysing Solution (Becton Dickinson). Plates were mixed by pipetting up and down and incubated for $10 \mathrm{~min}$ in the dark at room temperature. Plates were centrifuged at $450 \mathrm{x}$ for $5 \mathrm{~min}$ and after removal of the supernatant, $2 \mathrm{ml}$ of CellWASH (Becton Dickinson) was added to each well. Plates were centrifuged at $450 \mathrm{x}$ g for $5 \mathrm{~min}$ again, the supernatant removed and the cell pellet resuspended in $0.5 \mathrm{ml}$ CellWASH.

Data was acquired on a Becton Dickinson LSR II flow cytometer using BD FACSDiva software (version 4.1.2). Lymphocytes were gated in the FSC/SSC dot plot according to size and granularity and further analyzed for expression of CD19 and activation markers. Data were calculated from dot blots as percentage of cells positively stained for activation markers within the CD19+ population. 


\section{$\underline{\text { High-throughput equilibrium solubility }}$}

Sample preparation for high-throughput equilibrium solubility determination was performed in microtiter plate format. Starting from $10 \mathrm{mM}$ DMSO stock solution, each sample was dispensed in triplicates. The DMSO was evaporated in an evaporator (Combidancer, Hettich) under vacuum and moderate heat of 35 ${ }^{\circ} \mathrm{C}$. Afterwards the buffer media was added, the plate sealed and shaken overnight at $1000 \mathrm{rpm}$ (Tritrimax, Heidolph) at ambient temperature. After phase separation of supernatant and undissolved solid by centrifugation, an adequate volume of the supernatant was diluted for analysis. Quantitation was done using a four point external calibration curve, performed by mass spectrometry using LC-MS/MS (TSQ Discovery, Thermo). Data evaluation was performed by Excel (Microsoft) and results were stored in a proprietary laboratory information system.

\section{$\underline{\text { Kinase selectivity and safety panel assays for compound } 11}$}

List of lipid kinase assays:

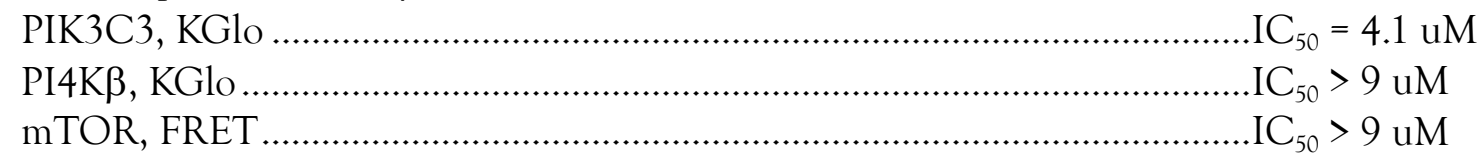

List of protein kinase assays, all $\mathrm{IC}_{50}>10 \mathrm{uM}$ :

ALK, ABL1, AKT1, AURKA, BTK, CDK2A, CDK4D1, GSK3B, JAK1, JAK2, JAK3, MAP3K8, MAPK1, MAPK14, MAPKAPK2, MAPKAPK5, MKNK2, PDPK1, PKN1, PKN2, PRKACA, PRKCA, PRKCQ, ROCK2, TYK2, EphA4, EphB4, FGFR4, FGFR3K, HER1, HER2, IGF1R, INS1R, KDR, LCK, PDGFRa, RET, SYK, cKIT, cMET

List of safety panel assays:

Adenosine 1 receptor binding assay, human recombinant.............................. $\mathrm{I}_{50}>30 \mathrm{uM}$

Adenosine 2A receptor binding assay, human recombinant ........................... $\mathrm{IC}_{50}>30 \mathrm{uM}$

Adenosine 3 receptor binding assay, human recombinant .............................. $\mathrm{IC}_{50}>30 \mathrm{uM}$

Adenosine Transporter binding assay, human non-recombinant ..................... $\mathrm{I}_{50}>30 \mathrm{uM}$

Adrenergic Alpha 2C receptor assay, human recombinant ............................. $\mathrm{I}_{50}>30 \mathrm{uM}$

Alpha1A receptor binding assay, human recombinant ................................. $\mathrm{IC}_{50}>30 \mathrm{uM}$

Androgen receptor agonist/antagonist FRET assay, rat recombinant................ $\mathrm{I}_{50}>30 \mathrm{uM}$

Angiotensin II AT1 receptor binding assay, human recombinant ................... $\mathrm{IC}_{50}>30 \mathrm{uM}$

Beta 1 adrenergic receptor assay, human recombinant ................................ $\mathrm{IC}_{50}>30 \mathrm{uM}$

Beta 2 adrenergic receptor assay, human recombinant ................................ $\mathrm{IC}_{50}>30 \mathrm{uM}$

Bradykinin 2 receptor binding assay, human recombinant ............................ $\mathrm{I}_{50}>30 \mathrm{uM}$

COX-1 assay, ovine recombinant ............................................................ $\mathrm{I}_{50}>30 \mathrm{uM}$

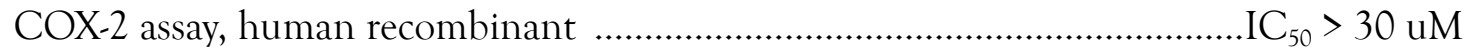

Cholecystokinin A receptor binding assay, human recombinant ..................... $\mathrm{I}_{50}>30 \mathrm{uM}$

Cholecystokinin B receptor binding assay, human recombinant .................... $\mathrm{IC}_{50}>30 \mathrm{uM}$

Dopamine D2 receptor assay, human recombinant .................................. $\mathrm{IC}_{50}>30 \mathrm{uM}$ 
Estrogen alpha receptor binding assay, human recombinant $\ldots \ldots \ldots \ldots \ldots \ldots \ldots . . . . . . . \mathrm{IC}_{50}>30 \mathrm{uM}$

Ghrelin receptor binding assay, human recombinant ................................. $\mathrm{I}_{50}>30 \mathrm{uM}$

Glucocorticoid receptor binding assay, human recombinant ......................... $\mathrm{IC}_{50}>30 \mathrm{uM}$

HERG dofetilide binding assay, human recombinant .................................. $\mathrm{IC}_{50}>30 \mathrm{uM}$

Histamine $\mathrm{H} 1$ receptor assay, human recombinant ................................... $\mathrm{IC}_{50}>30 \mathrm{uM}$

Human histamine $\mathrm{H} 3$ receptor binding assay ............................................ $\mathrm{IC}_{50}>30 \mathrm{uM}$

Melanocortin MC3 receptor binding assay, human recombinant ................... $\mathrm{IC}_{50}>30 \mathrm{uM}$

Melanocortin MC4 receptor binding assay, human recombinant .................... $\mathrm{I}_{50}>30 \mathrm{uM}$

Monoamine Oxidase A, human recombinant baculovirus ............................ $\mathrm{IC}_{50}>30 \mathrm{uM}$

Motilin receptor binding assay, human recombinant .................................... $\mathrm{I}_{50}>30 \mathrm{uM}$

Muscarinic M1 receptor assay, human recombinant .................................. $\mathrm{IC}_{50}>30 \mathrm{uM}$

Muscarinic M2 Calcium flux assay, agonist and antagonist mode ................... $\mathrm{IC}_{50}>10 \mathrm{uM}$

Nicotinic (CNS) Receptor binding in human IMR32 cells ............................. $\mathrm{I}_{50}>30 \mathrm{uM}$

Norepinephrine Transporter assay, human recombinant ............................. $\mathrm{IC}_{50}>30 \mathrm{uM}$

Opiate $\mathrm{Mu} \mathrm{OpM}$ receptor assay, human recombinant ................................... $\mathrm{I}_{50}>30 \mathrm{uM}$

Phosphodiesterase 3 from human platelets ................................................ $\mathrm{IC}_{50}>30 \mathrm{uM}$

Phosphodiesterase 4D, human recombinant ....................................... $\mathrm{IC}_{50}=7 \mathrm{uM}$

Progesteron receptor agonist/antagonist FRET assay, human recombinant $. \mathrm{IC}_{50}>30 \mathrm{uM}$

Serotonin Transporter assay, human recombinant ..................................... $\mathrm{I}_{50}>30 \mathrm{uM}$

Serotonin 5HT2A Calcium flux assay, agonist and antagonist mode............... $\mathrm{IC}_{50}>10 \mathrm{uM}$

\section{$\underline{\text { Animal studies - general }}$}

All aspects of animal care, use, and welfare for research animals used for in vivo studies were performed in compliance with local governmental regulations. Furthermore, all animals were handled in accordance with Novartis Animal Care and Use Committee approved protocols and regulations.

\section{$\underline{\text { PK/PD study }}$}

\section{$\underline{\text { Animals }}$}

PK/PD experiments were performed with adult male Lewis rats (LEW/HanHsd) weighing 220-280 g. SRBC experiments were performed with female albino OFA rats weighing 150 to $160 \mathrm{~g}$. Studies were performed according to the Swiss federal law for animal protection and approved by the Veterinary Office Basel (BS No. 425).

\section{$\underline{\text { Reagents }}$}

KZI/Gluc.5\%; 1 part 'Konzentrat zur Infusion' (Ethanol (Merck)/Cremophor EL (Fluka) 1+1 V/V) and 2 parts of D-Glucose (Fluka) Solution 5\% was used as the vehicle for oral compound administration. High molecular weight sodium heparin B.Braun (B.Braun, Melsungen, Germany; 5000 I.U./ml) was used as anticoagulant. 
Compound dosing, PK/PD blood collection

Compound 11 was administered p.o. at in a volume of $4 \mathrm{ml} / \mathrm{kg}$ body weight. For blood collection, animals were anaesthetized with isofluran using a Fluvac airflow system. Whole blood was collected from the abdominal aorta using a $10 \mathrm{ml}$ syringe with hypodermic needle pre-coated with sodium heparin. Blood was transferred into $50 \mathrm{ml}$ Falcon tubes and the anticoagulant concentration was adjusted to $100 \mathrm{U} / \mathrm{ml}$ final concentration.

Pharmacokinetic analysis of PK/PD experiment

For pharmacokinetic analysis, $150 \mu \mathrm{l}$ of each whole blood sample was stored at $-80{ }^{\circ} \mathrm{C}$ prior analysis. After addition of $20 \mu \mathrm{l}$ internal standard $(\mathrm{conc}=400 \mathrm{ng} / \mathrm{ml})$ to an $80 \mu \mathrm{l}$ aliquot of each whole blood sample, cells and proteins were removed by centrifugation following precipitation with $400 \mu \mathrm{l}$ acetonitrile. The organic upper layer was then evaporated to dryness. The residues were dissolved in $20 \%$ acetonitrile containing $0.2 \%$ formic acid, centrifuged and then stored at $10{ }^{\circ} \mathrm{C}$ prior to analysis. For calibration, 8 blank whole blood samples were spiked with amounts of compound from 1 to $1000 \mathrm{ng} / \mathrm{ml}$. Quality and recovery control samples were set to $100 \mathrm{ng} / \mathrm{ml}$.

For analysis, a $10 \mu \mathrm{l}$ aliquot of each sample extract was injected into a LC-MS system. Compounds were resolved on a Uptisphere 3 HDO C18 $0.5 \times 50 \mathrm{~mm}$ reversed phase column applying a linear gradient from $0.02 \%$ heptafluoro-butyric acid in water to acetonitrile, containing $0.02 \%$ trifluoroacetic acid, within 5 minutes. For detection, mass spectrometry in MRM (multiple reaction monitoring) was used. After ionization of the column effluent in an AP electrospray source, compound and internal standard were detected as their $[\mathrm{MH}]^{+}$product ions.

Compound concentrations were calculated by Thermo Xcalibur ${ }^{\circledR}$ and Excel®, based on the extracted peak area ratio, obtained from the relative intensity of the MS signals.

\section{$\underline{\mathrm{SRBC}}$}

Five female OFA rats per group were immunized on day 0 with $2 \times 10^{8} / \mathrm{ml}$ SRBCs (SRBC from Laboratory animal services LAS, Novartis) in a volume of $0.5 \mathrm{ml}$ by i.v. injection. Animals were treated for 4 consecutive days starting on the day of immunization.

Animals were euthanized with $\mathrm{CO}_{2} 4$ days after immunization. Agarose dishes were prepared, 0.7\% Agarose (SERVA) in Hanks Balanced Salt solution pH 7.3 (Gibco, added with $1 \mathrm{mg}$ Phenol red /100ml). Spleens were removed and a single cell suspension $\left(30 \times 10^{6} / \mathrm{ml}\right)$ of each animal was prepared and plated with fresh antigen (SRBC, $\left.40 \times 10^{8} / \mathrm{ml}\right)$ onto the soft agar $(50 \mu \mathrm{l}$ splenocytes $+50 \mu \mathrm{l} \mathrm{SRBCs})$. After an incubation for 60 minutes at $37^{\circ} \mathrm{C}, 1.4 \mathrm{ml}$ guinea pig complement $10 \%$ (Harlan) was added and incubation continued for another 60 minutes at $37^{\circ} \mathrm{C}$. During this time, B cells released antibodies formed against SRBCs, which, upon incubation bound to the antigen (SRBC) in the vicinity of the secreting B cells. This antigen-antibody complex activated complement and led to lysis of the complex leaving a bright spot (plaque) within the red antigen layer (erythrocytes). Plaques were counted with a microscope.

The following formula for calculation of \% Inhibition was used:

$\mathrm{C}^{*} 100 / \mathrm{V}-100$ with $\mathrm{V}=$ mean\# plaques/spleen for vehicle group; $\mathrm{C}=$ mean\# plaques/spleen for compound treated group.

For ex vivo PD analysis of blood from drug-treated animals, $90 \mu \mathrm{l}$ heparinized blood was mixed in $5 \mathrm{ml}$ U. bottom tubes (BD, cat\# 352063) with $100 \mu \mathrm{l}$ of RPMI medium (Gibco, cat\# 31870) immediately after 
blood collection, and activated with $10 \mu \mathrm{l}$ of anti-rat IgM/rIL-4 at a final concentration of anti-rat IgM of $50 \mu \mathrm{g} / \mathrm{ml}$ and $\mathrm{rIL}-4$ of $10 \mathrm{ng} / \mathrm{ml}$. Control samples were left unstimulated. Samples were then processed, stained for pAkt and CD86 and analyzed as described above.

Full statistics: At a dose of $10 \mathrm{mg} / \mathrm{kg}$ bid, plaque formation was inhibited by $79 \%$ from a mean of $4.18 \cdot 10^{5}$ $\mathrm{PFC} /$ spleen $\left(95 \% \mathrm{CI}=3.02 \cdot 10^{5}\right.$ to $\left.5.33 \cdot 10^{5}\right)$ to a mean of $8.89 \cdot 10^{4} \mathrm{PFC} /$ spleen $\left(95 \% \mathrm{CI}=4.47 \cdot 10^{4}\right.$ to $13.3 \cdot 10^{4}$, p $\left.<0.001\right)$. At $30 \mathrm{mg} / \mathrm{kg}$ bid, an inhibition of $94 \%$ from a mean of $4.1810^{5} \mathrm{PFC} / \mathrm{spleen}(95 \% \mathrm{CI}$ $=3.02 \cdot 10^{5}$ to $\left.5.33 \cdot 10^{5}\right)$ to a mean of $2.37 \cdot 10^{4} \mathrm{PFC} /$ spleen $\left(95 \% \mathrm{CI}=1.46 \cdot 10^{4}\right.$ to $\left.3.28 \cdot 10^{4}, \mathrm{p}<0.001\right)$ was achieved comparable to the inhibition seen with the positive control CsA (Cyclosporin A, mean $=3.00 \cdot 10^{4}$ $\mathrm{PFC} /$ spleen, $95 \% \mathrm{CI}=1.30 \cdot 10^{4}$ to $4.70 \cdot 10^{4}$, $\mathrm{p}<0.001$ ).

\section{$\underline{\text { Pharmacokinetic studies }}$}

\section{In vivo pharmacokinetic studies in rats}

Female wild-type Sprague Dawley rats (Iffa Credo, France) were kept in standard cages and conditions according to Swiss Animal Welfare guidelines (12h light/dark cycles, room temperature at $22-24{ }^{\circ} \mathrm{C}$, humidity at least $45 \%$ but $<70 \%$ ) with free access to Ringer solution (glucose $5 \%, \mathrm{NaCl} 0.9 \%$ and $\mathrm{KCl} 0.5 \%$ ) and pelleted rodent chow. 96-120 hours before administration of the test substance the animals were anesthetized with isoflurane and catheters were surgically implanted under aseptic precautions (use of sterile instruments and surgical material in combination with local antibiotic prophylaxis) into the femoral artery and vein. The catheters were exteriorized in the neck region, connected to a Harvard swivel system (Harvard Instruments) and filled with $0.9 \%$ saline containing $100 \mathrm{U} \square \mathrm{mL}^{-1}$ heparin. After recovery from anesthesia the animals were housed individually in special cages with free access to food and tap water until and throughout the experiment. Analgesic treatment with Temgesic ${ }^{\circledR}(10 \mu \mathrm{g} / \mathrm{kg}$ s.c., application volume $1 \mathrm{~mL} / \mathrm{kg}$ ) was performed in the evening following surgery and in the next morning. Compound administration was in the morning (6-8 AM). Blood samples were collected at various time points from the femoral artery catheter into Eppendorf tubes coated with sodium EDTA. Blood samples were immediately frozen at $-20{ }^{\circ} \mathrm{C}$ until final processing (maximum storage was 8 days). Intravenous and oral dosing was performed in the same animals after a $48 \mathrm{~h}$ wash-out interval between the single dose applications. The test substance was administered intravenously as a solution in 1-methyl-2-pyrrolidone and polyethylene glycol $200(30: 70, \mathrm{v} / \mathrm{v})$ at a dose of $1 \mathrm{mg} / \mathrm{kg}$ and orally as a homogenous aqueous suspension in Tween 80 and carboxy methyl cellulose sodium 0.5/0.5/99 (w/w) at a dose of $3 \mathrm{mg} / \mathrm{kg}$.

\section{In vivo pharmacokinetic studies in dogs}

Adult male beagle dogs (originating from Marshall Farms at Montichiari, Italy) from the permanent MAP/DMPK stock were kept under standard conditions in dog pens according to Swiss Animal Welfare guidelines (standard dog chow once daily, free access to tap water throughout the study). The dogs were fasted $12 \mathrm{~h}$ before dosing and then fed $2 \mathrm{~h}$ post dose. Compound administration was done in a cassette 
dosing format of five compounds and in the morning (7-8 AM). Intravenous and oral dosing was performed in different animals. The test substance were administered intravenously as a solution in 1-methyl2-pyrrolidone and polyethylene glycol $200(10: 90, \mathrm{v} / \mathrm{v})$ at a dose of $0.1 \mathrm{mg} / \mathrm{kg}$ and orally as a homogenous aqueous suspension in Tween 80 and carboxy methyl cellulose sodium 0.5/0.5/99 (w/w) at a dose of 0.3 $\mathrm{mg} / \mathrm{kg}$.

\section{Bioanalytical method for pharmacokinetics}

Chemicals and reagents: CHROMASOLV ${ }^{\circledR}$ Plus HPLC grade water (Sigma, Buchs, Switzerland) was further purified by distillation using a Water Still Distinction D4000 (GMB Glasmechanik, Therwil, Switzerland). CHROMASOLV ${ }^{\circledR}$ HPLC grade acetonitrile $(\mathrm{MeCN})$ and methanol $(\mathrm{MeOH})$, phosphate buffer (PBS, $1.0 \mathrm{M} \mathrm{pH} \mathrm{7.4),} \mathrm{trifluoroacetic} \mathrm{acid} \mathrm{(TFA),} \mathrm{nicotinamide} \mathrm{adenine} \mathrm{dinucleotide} \mathrm{2-phosphate} \mathrm{reduced}$ tetrasodium salt hydrate (NADPH), raloxifene, 1-methyl-2-pyrrolidone (NMP) and polyethylene glycol-200 (PEG200), uridine 5-diphosphoglucuronic acid trisodium salt (UDPGA), glutathione, isocitrate dehydrogenase, isocitrate, alamethicin and carboxy methyl cellulose sodium (C9481) were purchased from Sigma (Buchs, Switzerland). Tween 80 (Polysorbate 80, 59924) and ammonium bicarbonate was purchased from Fluka (Switzerland).

Optima LC/MS grade methanol and acetonitrile were purchased from Fisher Scientific (Waltham, Massachusetts USA). CHROMASOLV ${ }^{\circledR}$ NMR grade acetonitrile (used for metabolite desorption), ammonium formate and formic acid were purchased from Fluka (Buchs, Switzerland). Nitrogen (purity 99.5\%) and Argon (purity 99.995\%) were purchased from Carbagas (Lausanne, Switzerland). Perdeuterated dimethyl sulfoxide (DMSO-d6, 100 atom\% D) was purchased from Armar Chemicals (Döttingen, Switzerland).

Oasis HLB columns and SPE cartridges were purchased from Waters (Milford, Massachusetts USA). Synergi Polar-RP HPLC columns were purchased from Phenomenex (Brechbühler, Switzerland). XBridge BEH130 C18 HPLC columns were purchased from Waters (Switzerland). Maisch Reprosil C18 HPLC columns were purchased from Morvay (Basel, Switzerland).

Blood samples were spiked with a structurally closely related internal standard, then lysed and deproteinated using acetonitrile. After centrifugation the supernatant was evaporated to dryness. The remainder was re-dissolved in methanol (60\%) and 1\% aqueous formic acid ( $\mathrm{pH} 3.0)$. The solution was separated on a Synergi Polar-RP HPLC column (particle size: $2.5 \mu \mathrm{m}$; column dimensions: $2 \times 50 \mathrm{~mm}$ ) using a linear gradient (0 min, 98\% A/2\% B; $4.1 \mathrm{~min}, 30 \% \mathrm{~A} / 70 \% \mathrm{~B} ; 4.2 \mathrm{~min}, 1 \% \mathrm{~A} / 99 \% \mathrm{~B} ; 5.4 \mathrm{~min}, 1 \% \mathrm{~A} / 99 \% \mathrm{~B}$ at a flow rate of 0.35 or $0.45 \mathrm{~mL} / \mathrm{min}$. Mobile phase A consisted of $1 \%$ formic acid in HPLC grade water. Mobile phase B consisted of 1\% formic acid in HPLC grade acetonitrile. The flow from the HPLC system was directly introduced into the ion source of a Sciex Q-Trap 5500 mass spectrometer (AB Sciex, Massachusetts, USA) and subjected to electrospray ionization (positive ion mode). The test substance was detected via a specific daughter ion of its protonated quasi-molecular ion. Quantitation of blood levels of the test substance was based on a 8-level calibration curve (in triplicate) using blank rat blood samples spiked with stock solutions of external and internal standards. 


\section{Supplementary Table 1. PK parameters ${ }^{\mathrm{a}}$ for compounds $6 \mathrm{~d}$ and 11.}

\begin{tabular}{|c|c|c|c|c|c|c|c|}
\hline Compound (route of administration) & $6 d$ (i.v.) & $6 \mathrm{~d}$ (p.o.) & 11 (i.v.) & 11 (р.о.) & 11 (р.о.) & 11 (i.v.) & 11 (р.о.) \\
\hline Species (gender) & Rat (female) ${ }^{b}$ & Rat $(\text { female })^{b}$ & Rat (female) & Rat (female) & Rat (female) & Dog (male) & Dog (male) \\
\hline Dose $\left[\mathrm{mg} \cdot \mathrm{kg}^{-1}\right]$ & 1 & 3 & 1 & 3 & 30 & 0.1 & 0.3 \\
\hline $\mathrm{CL}\left[\mathrm{mL} \cdot \mathrm{min}^{-1} \cdot \mathrm{kg}^{-1}\right]$ & $33(4)$ & & $15(3)$ & & & $13(3)$ & \\
\hline $\mathrm{V}_{\mathrm{SS}}\left[\mathrm{L} \cdot \mathrm{kg}^{-1}\right]$ & $3.9(0.5)$ & & $2.0(0.3)$ & & & $1.0(0.2)$ & \\
\hline $\mathrm{t}_{1 / 2}$ term. $[\mathrm{h}]$ & $2.1(0.4)$ & & $2.0(0.5)$ & & & $0.9(0.1)$ & \\
\hline AUC d.n. ${ }^{c}[\mathrm{nM} \cdot \mathrm{h}]$ & $1152(148)$ & $918(144)$ & $2315(537)$ & $500(168)$ & $237(24)$ & $2798(715)$ & $1188(251)$ \\
\hline abs. oral BAV [\%] & & $80(13)$ & & $22(7)$ & $10(1)$ & & $42(9)$ \\
\hline $\mathrm{C}_{\max }$ d.n. ${ }^{c}[\mathrm{nM}]$ & & $230(92)$ & & $48(14)$ & $20(4)$ & & $440(112)$ \\
\hline $\mathrm{T}_{\max }[\mathrm{h}]$ & & $0.7^{\mathrm{d}}$ & & $3.5(3.1)$ & $5.3(2.2)$ & & $0.8(0.3)$ \\
\hline
\end{tabular}




\section{$\underline{\text { Structural biology }}$}

The human protein was used for PI3K $\alpha$ and the mouse protein for PI3K $\delta$. The only isoform divergence within $12 \AA$ of the ligand binding site is amino acid 830 (R830 in the human sequence, H830 for mouse), both residues are solvent exposed (see Supplementary Figure 1). Based on at least partial protonation of $\mathrm{H} 830$ at physiological $\mathrm{pH}$, we are confident that the $\mathrm{PI} 3 \mathrm{~K} \delta$ structure of compound 11 with the mouse protein is very close to that of the human protein.

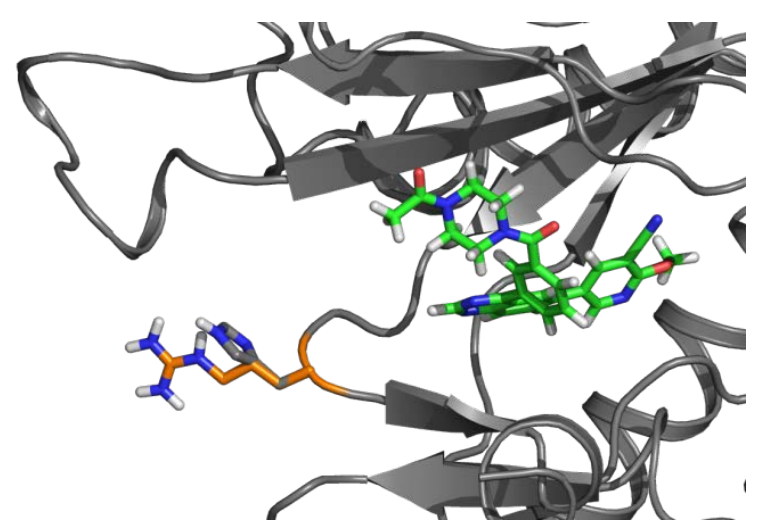

Supplementary Figure 1. Difference between human and mouse PI3K $\delta$ around the ligand binding site: R830 (orange) in human versus $\mathrm{H} 830$ in mouse.
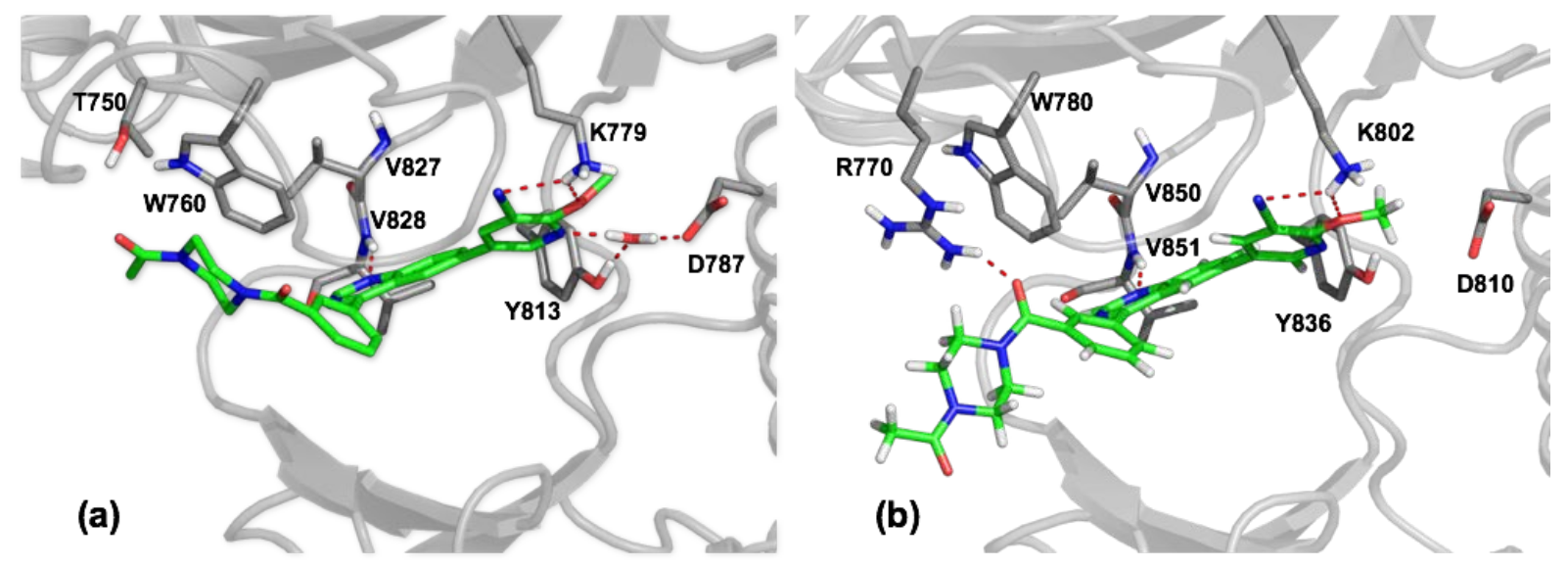

Supplementary Figure 2. Main interactions of compound 11 in PI3K $\delta$ (a) and PI3Ka (b).

\section{Expression and purification (PI3K $\alpha)$}

PI3Ka BV2244 p85(307-593) + p110 $\alpha($ M232K/L233K) was expressed in Tn5 insect cells. Cell pellets were resuspended in Buffer A + $5 \mathrm{mM}$ imidazole + Benzonase (1:10K dilution), 1:6 (pellet:lysate volume) 
and lysed by Dounce, 20 strokes. The lysate was cleared by centrifugation, 20K rpm in Beckman JA-20 rotor for $30 \mathrm{~m}$. The first step of purification was performed by immobilized metal ion affinity column (IMAC:Nickel SepharoseFF) with one wash with Buffer B, followed by step elution with Buffer C. The pooled IMAC fractions were adjusted with 10mM EDTA. IMAC fractions were diluted with 15x Buffer D and purified over Ion Exchange Column, Sepharose SP-HP, with a gradient from $30 \mathrm{mM}$ to $500 \mathrm{mM}$ over 20 CV using Buffer E and Buffer F. Concentrated IEX fractions with 50K MWCO were loaded onto gel filtration column (Superdex 200) pre-equilibrated with Buffer G. Final sample was concentrated 6$6.5 \mathrm{mg} / \mathrm{mL}$.

Buffer A: $20 \mathrm{mM}$ Tris pH 7.5, $500 \mathrm{mM} \mathrm{NaCl,} 1 \mathrm{mM} \mathrm{MgCl2,} \mathrm{1 \%} \mathrm{Betaine,} \mathrm{1 \%} \mathrm{Ethylene} \mathrm{Glycol,}$ 1xComplete Protease Inhibitor Tablet, $5 \mathrm{mM}$ bME.

Buffer B: Buffer A + 45 mM Imidazole

Buffer C: Buffer A + 250 mM Imidazole

Buffer D: 50 mM Hepes pH 7.5, 1\% Betaine, 1\% Ethylene Glycol, 0.02\% CHAPS, 5 mM DTT

Buffer E: Buffer D + 30 mM NaCl

Buffer F: BufferD + $1 \mathrm{M} \mathrm{NaCl}$

Buffer G: 20 mM Tris pH 7.2, 200 mM NaCl, 1\% Betaine, 1\% Ethylene Glycol, 0.02\% CHAPS, 5 mM DTT

\section{Co-crystallization of the PI3K $\alpha /$ compound 11 complex and structure refinement}

Compound 11, dissolved in DMSO, was added to the protein solution containing PI3Ka to a final concentration of $1 \mu \mathrm{M}$. This solution was incubated on ice for $1 \mathrm{~h}$ and then passed through a $0.2 \mu \mathrm{m}$ filter. Crystals were grown by the hanging-drop vapor diffusion method at $30{ }^{\circ} \mathrm{C}$ by mixing $5 \mu \mathrm{L}$ proteininhibitor solution with $3 \mu \mathrm{L}$ well solution composed of $120 \mathrm{mM}$ potassium thiocyanate and $12 \% \mathrm{w} / \mathrm{v}$ polyethylene glycol (PEG) 3350. The drops were streak seeded and then sealed with a screw cap. Crystals were transferred to a new drop containing the well solution supplemented with $20 \%$ ethylene glycol and then flash cooled in liquid nitrogen. Diffraction data was collected at beamline 5.0.2 of the Advanced Light Source.

The diffraction images were integrated and data scaled and merged with autoPROC. The initial structural solution was solved by Molecular Replacement using Phaser and an in-house model. The structure was improved to convergence through successive rounds of rebuilding and refinement using $\operatorname{Coot}^{1}$ and autoBuster, ${ }^{2}$ respectively.

\section{Expression and purification (PI3K $\delta)$}

Virus stock was obtained from the laboratory of Roger Williams (Medical Research Council, Laboratory of molecular biology, Cambridge, UK). 
5L- bottles with a culture volume of $3.7 \mathrm{~L}$ were used for the large-scale expression. Sf9-DE cells were diluted at a density of $1.5 \times 10^{6} \mathrm{ml}^{-1}$ in SF4 medium. Recombinant baculoviruses were added simultaneously at 10 - 20 parts of $\mathrm{PI} 3 \mathrm{~K} \delta$ and 1 part for $\mathrm{iSH} 2 \mathrm{p} 85 \alpha$ (dependent on virus batch and as determined by functional titration). The culture was incubated at $27^{\circ} \mathrm{C}$ and shaken at $120 \mathrm{rpm}$. At $48 \mathrm{~h}-72 \mathrm{~h}$ post infection when the viability was less than $80 \%$ the culture was harvested by centrifugation at $500 \mathrm{x}$ g for 20 min at room temperature. The pellet was stored at $-80^{\circ} \mathrm{C}$.

Purification was performed as described ${ }^{3}$ with minor modifications. Briefly, after thawing of the cell pellet

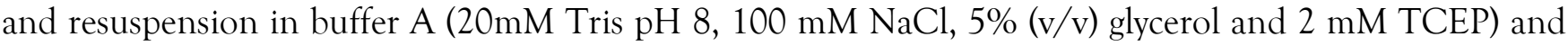
addition of Complete EDTA-free proteinase inhibitors (Boehringer), the cells were lysed manually using a glass homogenizer. After spinning down the lysate at $42,000 \mathrm{rpm}$ for 45 minutes, the supernatant was filtered and loaded onto a NiNTA column (GE healthcare). After washing with buffer A, the column was eluted using a gradient from $0-100 \%$ buffer B (buffer A $+200 \mathrm{mM}$ imidazole). Fractions of the PI3K $\delta$ iSH2 complex were pooled and loaded onto a heparin column equilibrated with heparin A buffer (20 $\mathrm{mM}$ Tris $\mathrm{pH} 8,100 \mathrm{mM} \mathrm{NaCl}, 2 \mathrm{mM}$ TCEP) then the column was washed and eluted with a gradient from $0-100 \%$ heparin $B$ buffer (heparin $A+1 \mathrm{M} \mathrm{NaCl}$ ), to separate the excess His6-iSH2 from the

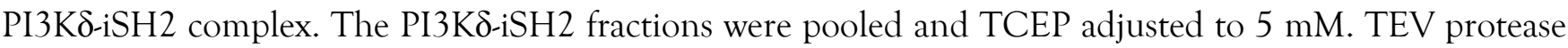
was added and the mixture incubated overnight at $4{ }^{\circ} \mathrm{C}$. The resulting solution was adjusted to $30 \mathrm{mM}$ imidazole and passed over a second NiNTA column to remove the cleaved ABD/His6-iSH2 PI3K $\delta$ was collected in the flow-through, and $\mathrm{NaNO}_{4}$ was added to a final concentration of $100 \mathrm{mM}$. Following a concentration step the protein was subjected to gel filtration on an S200 16/60 HiLoad column (GE healthcare) and eluted in $20 \mathrm{mM}$ Tris $\mathrm{pH}$ 7.2, $50 \mathrm{mM}$ ammonium sulphate, $1 \%$ (v/v) ethylene glycol, 1 $\%(\mathrm{w} / \mathrm{v})$ betaine, $0.2 \%$ CHAPS and $5 \mathrm{mM}$ TCEP. Fractions were then pooled and concentrated to 5 $\mathrm{mg} / \mathrm{ml}$, flash frozen in liquid $\mathrm{N}_{2}$ and stored at $-80{ }^{\circ} \mathrm{C}$.

To prepare the complex with inhibitor, $0.2 \mu \mathrm{l}$ of compound 11 in a $100 \mathrm{mM}$ stock solution of $100 \%$ DMSO was mixed with $2.4 \mu \mathrm{l}$ of $5 \%(\mathrm{w} / \mathrm{v})$ dodecylmaltoside and $22 \mu \mathrm{l}$ of PI3K $\delta$ at $6 \mathrm{mg} / \mathrm{ml}$, incubated at RT for $30 \mathrm{~min}$ and then spun for $5 \mathrm{~min}$. The supernatant was used to set up the crystallization drop.

\section{Co-crystallization of the PI3Kס/compound 11 complex}

Plate-like crystals were obtained by the sitting drop vapor diffusion method at $17^{\circ} \mathrm{C}(290 \mathrm{~K})$ after mixing $0.25 \mu \mathrm{L}$ of complex at $6 \mathrm{mg} / \mathrm{ml}$ protein concentration with $0.16 \mu \mathrm{L}$ volume of reservoir solution consisting of $13 \mathrm{mM} \mathrm{NaNO}_{4}, 13 \mathrm{mM}$ ammonium sulfate, $13 \mathrm{mM} \mathrm{Na}_{2} \mathrm{HPO}_{4}, 16.4 \%$ (v/v) glycerol, 13\% (w/v)

PEG4000 and 0.1M imidazole pH6.8 in 96-well MRC-SD2 crystallisation plates. Crystals were harvested from their mother liquor and directly flash-frozen in liquid nitrogen.

\section{X-ray diffraction data collection and processing (PI3K $\delta)$}

Data sets were collected at $1.0 \AA$ wavelength with a PILATUS 6M detector at the Swiss Light Source beamline X10SA (Villigen, Switzerland). Diffraction data were collected by Expose GmbH. Diffraction images recorded at $0.25^{\circ}$ oscillation angle wedges were processed and scaled using XDS and XSCALE, ${ }^{4}$ 
respectively, in the APRV program suite..$^{5}$ Data collection and processing statistics are summarized in supplementary Table 2 .

Supplementary Table 2. Summary of data collection and processing statistics*

\begin{tabular}{|c|c|c|}
\hline Data set name & $\begin{array}{l}\text { PI3K } \delta / \text { compound } 11 \\
\text { (PDB ID 5IS5) }\end{array}$ & $\begin{array}{l}\text { PI3Ka/compound } 11 \\
\text { (PDB ID 5ITD) }\end{array}$ \\
\hline Space group name & $\mathrm{C} 2$ & P212121 \\
\hline Unit cell a $[\AA]$ & 141.8 & 104.6 \\
\hline Unit cell b $[\AA]$ & 64.6 & 107.2 \\
\hline Unit cell c $[\AA]$ & 116.7 & 134.6 \\
\hline Unit cell alpha $\left[^{\circ}\right]$ & 90.0 & 90.0 \\
\hline Unit cell beta $\left[^{\circ}\right]$ & 103.2 & 90.0 \\
\hline Unit cell gamma $\left[^{\circ}\right]$ & 90.0 & 90.0 \\
\hline Resolution $[\AA]$ & $69.9-2.6(2.68-2.61)$ & $83.86-2.82(2.82-2.83)$ \\
\hline Rsym [\%] & $10.1(47.7)$ & $7.7(91.5 .8)$ \\
\hline $\mathrm{I} / \operatorname{sig}(\mathrm{I})[\%]$ & $10.1(2.7)$ & $20.4(2.3)$ \\
\hline Completeness [\%] & $98.0(99.1)$ & $98.6(100.0)$ \\
\hline Redundancy/Multiplicity [\%] & $3.3(3.4)$ & $7.3(7.4)$ \\
\hline Number of observed reflections (overall) & 102166 & 268859 \\
\hline Number of unique reflections (overall) & 30985 & 36718 \\
\hline Wilson Bfactor $\left[\AA^{2}\right]$ & 49.8 & 70.5 \\
\hline
\end{tabular}

*Values in parentheses are for highest resolution shell.

\section{Structure determination and refinement $(\mathrm{PI} 3 \mathrm{~K} \delta)$}

Coordinates of the protein component of a published PI3K $\delta$ structure (PDB $2 \mathrm{wxf}$ ) were refined against experimental data using autoBuster in order to obtain a start model and electron density maps. The initial model was subjected to iterative cycles of manual rebuilding and subsequent structure refinement in Coot and autoBuster, respectively. The ligand structure was built into unbiased Fo-Fc difference electron density calculated by autoBuster. Final structure refinement statistics are summarized in Supplementary Table 3. Refined coordinates were deposited to the PDB with entry number [PDB ID 5IS5].

Supplementary Table 3. Summary of refinement statistics

\begin{tabular}{|c|c|c|}
\hline Structure & $\mathrm{PI} 3 \mathrm{~K} \delta /$ compound 11 & PI3Ka/compound 11 \\
\hline Resolution $[\AA ̊]$ & $65.95-2.85$ & $83.86-3.02$ \\
\hline No. reflections & 23616 & 29827 \\
\hline Rwork/Rfree & $0.2294 / 0.2709$ & $0.1907 / 0.2545$ \\
\hline \multicolumn{3}{|l|}{ No. atoms } \\
\hline Protein & 5648 & 9772 \\
\hline
\end{tabular}




\begin{tabular}{lll}
\hline Solvent & 232 & 51 \\
R.m.s devations & & \\
Bond lengths $[\AA]$ & 0.008 & 0.010 \\
Bond angles $\left[{ }^{\circ}\right]$ & 0.97 & 1.10 \\
\hline
\end{tabular}

\section{$\underline{\text { In silico methods }}$}

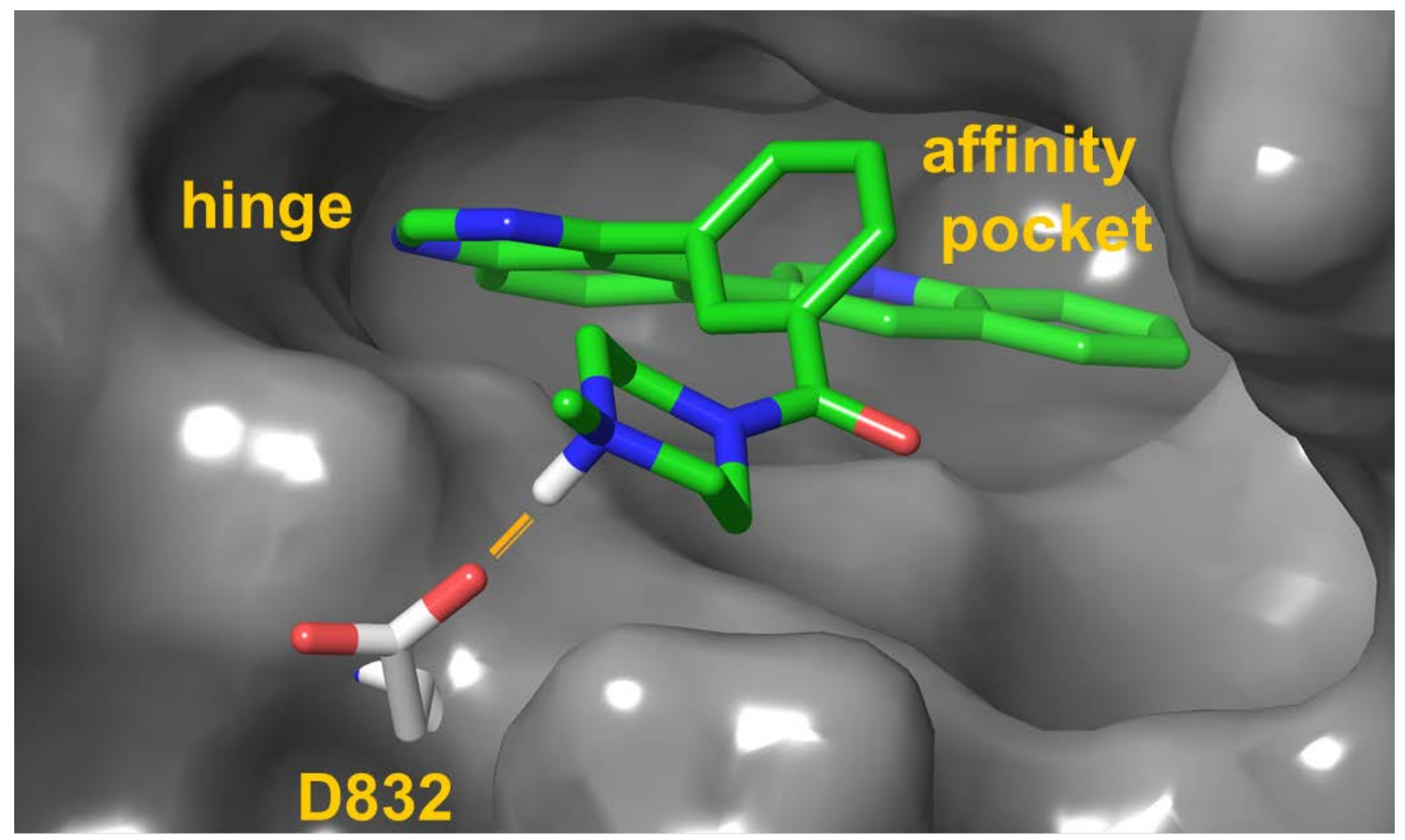

Supplementary Figure 3. Compound $2 \mathrm{~d}$ docked into a homology model of PI3K $\delta$ (based on a crystal structure of PI3K $\gamma$ ).

For further force field refinement of the protein-ligand complexes, only the following residues were used: for PI3Ka, residues A657 to C862 and N873 to T1052, for PI3K 8 , sequences L638 to N840, A848 to N918, and R929 to S1026. All resulting N- and C-termini were capped by acetyl and N-methyl, respectively. Water molecules further away than $8 \AA$ of any ligand heavy atom were discarded.

The structures were prepared with the ff14SB force field ${ }^{6}$ for the protein and the GAFF force field ${ }^{7}$ for the ligand compound 11. mbondi2 atom radii were assigned for subsequent Generalized-Born (GB) implicit solvent computations. Partial charges on compound 11 were generated with the AM1/BCC approach. ${ }^{8}$ 
The energy was refined with sander (AmberTools15), ${ }^{9}$ using the GB option igb $=5$, running 500 steps of conjugate gradient, with virtually no cutoff for non-bonded interactions (cut=99.0). All C $\alpha$ atoms were constrained with a harmonic force of $1 \mathrm{kcal} / \mathrm{mol} / \AA^{2}$ to their original positions.

MM/GBSA computations were carried out on the resulting energy-minimized structures after discarding all explicit water molecules, using the GB options $i g b=2$ and 5 (both compatible with the mbondi2 radius settings chosen during the data preparation).

\section{Experimental part chemistry}

\section{General}

Unless otherwise stated, all reagents and solvents were purchased from commercial suppliers and used without further purification. ${ }^{1} \mathrm{H}$ NMR spectra were recorded on a Bruker $400 \mathrm{MHz}$ or a Bruker $600 \mathrm{MHz}$ NMR spectrometer. Chemical shifts are reported in parts per million (ppm) relative to an internal solvent reference. Recorded peaks are listed in the order multiplicity (s, singlet; d, doublet; $t$, triplet; q, quartet; qt, quintet; m, multiplet; br, broad), coupling constants, and number of protons. Final compounds were purified to $\geq 95 \%$ purity as assessed by analytical liquid chromatography using the methods below. High resolution mass analyses (HRMS) were performed by using electrospray ionization in positive mode after separation by liquid chromatography. The elemental composition was derived from the averaged mass spectra acquired at a high resolution of about 30000 on an LTQ Orbitrap XL mass spectrometer (Thermo Scientific). The high mass accuracy below $1 \mathrm{ppm}$ was obtained by using a lock mass.

HPLC Method 1: column XBridge MS C18 30/3.0 2.5m at $40^{\circ} \mathrm{C}$; eluent A: water $+0.1 \%$ formic acid; eluent B: acetonitrile $+0.1 \%$ formic acid; gradient: from 10 to $95 \%$ B in $1.7 \mathrm{~min}$; flow $1.2 \mathrm{~mL} / \mathrm{min}$.

UPLC Method 2: column Acquity HSS T3 1.8um 2.1 x $50 \mathrm{~mm}$ at $60{ }^{\circ} \mathrm{C}$; eluent A: water $+0.05 \%$ formic acid $+3.75 \mathrm{mM}$ ammonium acetate; eluent B: acetonitrile $+0.04 \%$ formic acid; gradient: from 5 to $98 \%$ B in $1.4 \mathrm{~min}$; flow $1.0 \mathrm{~mL} / \mathrm{min}$. 
General synthetic sequence towards 4,6-diaryl quinazolines<smiles>O=c1[nH]cnc2ccc(Br)cc12</smiles>

A

1. c)

2. a)

3. b) or b')

,

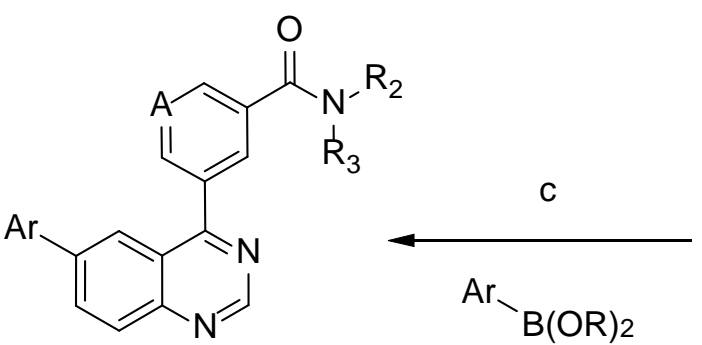

D<smiles>Clc1ncnc2ccc(Br)cc12</smiles>

B<smiles>[R10]c1cccc(C(=O)OCC)c1</smiles>

$b^{\prime}$

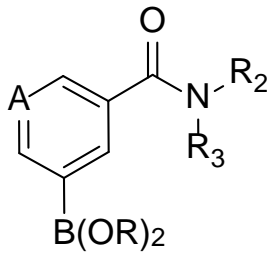

Supplementary Scheme 1: General synthetic sequence towards 4,6-diaryl quinazolines. Reagents and conditions: a) $\mathrm{POCl}_{3}$ neat, $80 \%$; b) i. $\mathrm{Pd}(0), \mathrm{K}_{3} \mathrm{PO}_{4}, \mathrm{CH}_{3} \mathrm{CN}, 31-72 \%$; ii. $\mathrm{LiOH}$, dioxane, 88-98\%; iii. Amine, HBTU, DIPEA, $\mathrm{CH}_{2} \mathrm{Cl}_{2}, 81-97 \%$; b') $\mathrm{Pd}(0), \mathrm{K}_{3} \mathrm{PO}_{4}, \mathrm{CH}_{3} \mathrm{CN}, 17-24 \%$; c) $\mathrm{Pd}(0), \mathrm{Na}_{2} \mathrm{CO}_{3}, \mathrm{DME}$, $\mathrm{H}_{2} \mathrm{O}, 24-60 \%$.

Two routes towards 4,6-diaryl quinazolines are outlined in Supplementary Scheme 1. In the first route outlined by the solid arrows, 6-bromoquinazolin-4 $(3 \mathrm{H})$-one $\mathrm{A}$ was converted to 6-bromo-4chloroquinazoline $\mathrm{B}$ using neat $\mathrm{POCl}_{3}$. The aromatic substituent in position 4 was then installed using a $\operatorname{Pd}(0)$ catalyzed Suzuki coupling $(\rightarrow \mathrm{C})$. Aromatic amides were introduced in one step (b), whereas aromatic esters were converted to the corresponding amides via saponification and amide bond formation following the cross-coupling reaction (b'). Finally, the position 6 aromatic ring was attached using another $\operatorname{Pd}(0)$ catalyzed cross-coupling to yield final compounds of type $\mathbf{D}$. As indicated by the dashed arrow, this general sequence was also used in reversed order. Overall, this modular approach enabled the chemistry team to modify either aromatic ring and/or the amide as the final synthetic step allowing for maximal diversity in the most efficient manner.

Synthesis and full characterization of 5-(4-(3-(4-acetylpiperazine-1-carbonyl)phenyl)quinazolin-6-yl)-2methoxynicotinonitrile (11) 
<smiles>Clc1ncnc2ccc(Br)cc12</smiles>

6-bromo-3H-quinazolin-4-one (20 g, $89 \mathrm{mmol})$ was suspended in phosphorus oxychloride $(140 \mathrm{ml})$, and the resulting mixture was stirred for $3 \mathrm{~h}$ at $\mathrm{rt}$. After that time, the reaction mixture was concentrated under reduce pressure. The residue was dissolved in dichloromethane $(500 \mathrm{ml})$ and neutralized with solid $\mathrm{NaHCO}_{3}(200 \mathrm{~g})$. The mixture was filtered, and the filtrate was concentrated under reduce pressure to yield the title compound ( $21 \mathrm{~g}, 86.2 \mathrm{mmol}, 95 \%) .{ }^{1} \mathrm{H}-\mathrm{NMR}\left(400 \mathrm{MHz}, \mathrm{CDCl}_{3}\right): \delta 7.98(\mathrm{~d}, 1 \mathrm{H}) 8.09(\mathrm{~d}$, 1H) $8.5(\mathrm{~s}, 1 \mathrm{H}) 9.1(\mathrm{~s}, 1 \mathrm{H})$. HPLC/MS Method 1: $1.24 \mathrm{~min}, 243.0[\mathrm{M}+\mathrm{H}]^{+}$.

Ethyl 3-(6-bromoquinazolin-4-yl)benzoate<smiles>CCOC(=O)c1cccc(-c2ncnc3ccc(Br)cc23)c1</smiles>

6-Bromo-4-chloroquinazoline $(2.0 \mathrm{~g}, 8.21 \mathrm{mmol})$, (3-(ethoxycarbonyl)phenyl)boronic acid (1.673 g, 8.62 $\mathrm{mmol}), \mathrm{Pd}\left(\mathrm{PPh}_{3}\right)_{2} \mathrm{Cl}_{2}(0.288 \mathrm{~g}, 0.411 \mathrm{mmol})$ and $\mathrm{K}_{3} \mathrm{PO}_{4}(2.62 \mathrm{~g}, 12.32 \mathrm{mmol})$ were dissolved in acetonitrile $(16 \mathrm{ml})$. The reaction mixture was flushed with argon, then $\mathrm{H}_{2} \mathrm{O}(2 \mathrm{ml})$ was added, and the tube was capped and heated to $100^{\circ} \mathrm{C}$ for $15 \mathrm{~min}$ in a microwave oven. After cooling, the formed yellow solid was filtered, washed with ether and dried under reduce pressure to yield the title compound (1.54 g, 4.3 $\mathrm{mmol}$ ) as a yellow solid. EtOAc was added to the filtrate, after phase separation the organic layer was washed with brine, dried $\left(\mathrm{MgSO}_{4}\right)$, filtered and concentrated under reduced pressure. The obtained residue was triturated with $\mathrm{MeOH}$ to afford the title compound as a yellow solid (580 $\mathrm{mg}, 1.6 \mathrm{mmol}$ ). The two solids were combined to yield the title compound $(2.12 \mathrm{~g}, 5.9 \mathrm{mmol}, 72 \%)$ as a yellow solid. ${ }^{1} \mathrm{H}-\mathrm{NMR}$ (400 MHz, CD $3 \mathrm{OD}): \delta 1.42(\mathrm{t}, 3 \mathrm{H}) 4.43(\mathrm{q}, 2 \mathrm{H}) 7.77(\mathrm{t}, 1 \mathrm{H}) 7.97-8.07(\mathrm{~m}, 2 \mathrm{H}) 8.16(\mathrm{dd}, 1 \mathrm{H}) 8.22(\mathrm{~d}, 1 \mathrm{H})$ $8.29(\mathrm{~d}, 1 \mathrm{H}) 8.41(\mathrm{~s}, 1 \mathrm{H}) 9.34(\mathrm{~s}, 1 \mathrm{H})$. HPLC/MS Method 1: $1.52 \mathrm{~min}, 357.0[\mathrm{M}+\mathrm{H}]^{+}$.

3-(6-Bromoquinazolin-4-yl)benzoic acid<smiles>O=C(O)c1cccc(-c2ncnc3ccc(Br)cc23)c1</smiles> 
An aqueous solution of $\mathrm{LiOH}_{\mathrm{H}} \mathrm{O}$ ( $(1.0 \mathrm{M}, 8.22 \mathrm{ml}, 8.22 \mathrm{mmol})$ was added to a solution of ethyl 3-(6bromoquinazolin-4-yl)benzoate $(1.41 \mathrm{~g}, 4.11 \mathrm{mmol})$ in dioxane $(45 \mathrm{ml})$, and the reaction mixture was stirred for $3 \mathrm{~h}$ at $\mathrm{rt}$. The reaction mixture was quenched with the addition of an aqueous solution of $\mathrm{HCl}$ $(1.0 \mathrm{M}, 5 \mathrm{~mL})$, and the formed precipitate was filtered and dried under vacuum to yield the title compound (880 mg, $2.67 \mathrm{mmol}$ ) as a light yellow solid. The filtrate was extracted with EtOAc, the organic layer was washed with brine, dried $\left(\mathrm{MgSO}_{4}\right)$ and concentrated under reduced pressure to give the title compound (555 mg, $1.68 \mathrm{mmol}$ ) as a light yellow solid. The two isolated solids were combined to yield the title compound (1.34 g, $4.07 \mathrm{mMol}, 99 \%)$ which was used in the next step without further purification. HPLC/MS Method 1: $1.14 \mathrm{~min}, 331.0[\mathrm{M}+\mathrm{H}]^{+}$.

1-(4-(3-(6-Bromoquinazolin-4-yl)benzoyl)piperazin-1-yl)ethan-1-one<smiles>CC(=O)N1CCN(C(=O)c2cccc(-c3ncnc4ccc(Br)cc34)c2)CC1</smiles>

HBTU (2.53 g, $6.68 \mathrm{mmol})$ and DIPEA $(2.12 \mathrm{~mL}, 12.2 \mathrm{mmol})$ were added to a solution of 3-(6bromoquinazolin-4-yl)benzoic acid $(2.0 \mathrm{~g}, 6.08 \mathrm{mmol})$ in dichloromethane $(60 \mathrm{ml})$. The reaction mixture was stirred for $10 \mathrm{~min}$ at $\mathrm{rt}$, then 1-(piperazin-1-yl)ethan-1-one $(0.935 \mathrm{~g}, 7.29 \mathrm{mmol})$ was added, and the reaction mixture was stirred at $\mathrm{rt}$ for a further $2 \mathrm{~h}$. The reaction mixture was quenched with a saturated aqueous $\mathrm{NaHCO}_{3}$ solution, and then extracted with dichloromethane. The organic layer was washed with brine, dried $\left(\mathrm{MgSO}_{4}\right)$ and concentrated under reduce pressure. The product was purified by flash chromatography using a dichloromethane/methanol gradient to yield the title compound $(2.64 \mathrm{~g}, 6.02 \mathrm{mmol}$, 99\%). ${ }^{1} \mathrm{H}-\mathrm{NMR}\left(400 \mathrm{MHz}, \mathrm{DMSO}-\mathrm{d}_{6}\right.$ ): $\delta 2.03$ (br s , 3H) 3.52 (br s, 8H) 7.69-7.76 (m, 2H) 7.84 (s, 1H) $7.91(\mathrm{~d}, 1 \mathrm{H}) 8.09(\mathrm{~d}, 1 \mathrm{H})$ 8.19-8.22 (m, 2H) $9.43(\mathrm{~s}, 1 \mathrm{H})$. HPLC/MS Method 1: $1.02 \mathrm{~min}, 439.6[\mathrm{M}+\mathrm{H}]^{+}$.

5-(4-(3-(4-Acetylpiperazine-1-carbonyl)phenyl)quinazolin-6-yl)-2-methoxynicotinonitrile (11)<smiles>COc1ncc(-c2ccc3ncnc(-c4cccc(C(=O)N5CCN(C(C)=O)CC5)c4)c3c2)cc1C#N</smiles>

2-Methoxy-5-(4,4,5,5-tetramethyl-1,3,2-dioxaborolan-2-yl)nicotinonitrile $(89 \mathrm{mg}, \quad 0.273 \mathrm{mmol})$ and $\mathrm{Pd}\left(\mathrm{PPh}_{3}\right)_{4} \quad(13 \mathrm{mg}, \quad 0.011 \mathrm{mmol})$ were added to a mixture of 1-(4-(3-(6-bromoquinazolin-4yl)benzoyl)piperazin-1-yl)ethan-1-one $(100 \mathrm{mg}, 0.228 \mathrm{mmol})$ in DME $(3 \mathrm{ml})$. The reaction mixture was flushed with argon, an aqueous $\mathrm{Na}_{2} \mathrm{CO}_{3}$ solution $(1.0 \mathrm{M}, 0.455 \mathrm{~mL}, 0.455 \mathrm{mmol})$ was added, and the vial 
was capped. The reaction mixture was heated to $140{ }^{\circ} \mathrm{C}$ for $10 \mathrm{~min}$ in a microwave oven. After cooling to $\mathrm{rt}$, the mixture was diluted with EtOAc, filtered through a pad of celite and partitioned between $\mathrm{H}_{2} \mathrm{O} /$ EtOAc. The organic layer was washed with brine, dried $\left(\mathrm{MgSO}_{4}\right)$ and concentrated under reduced pressure. The product was purified by preparative reverse phase HPLC HPLC (Waters Sunfire C18 OBD $30 \times 100 \mathrm{~mm}$, flow $30 \mathrm{ml} / \mathrm{min}$, water $+0.1 \%$ TFA and acetonitrile $+0.1 \%$ TFA gradient), subsequent neutralization of the combined fractions using $\mathrm{PL}_{-} \mathrm{HCO}_{3} \mathrm{MP}$ gave the title compound $(47 \mathrm{mg}, 0.095 \mathrm{mmol}$, $41 \%$ yield) as a white powder. ${ }^{1} \mathrm{H}-\mathrm{NMR}\left(500 \mathrm{MHz}, \mathrm{DMSO}_{6}\right): \delta 9.36(\mathrm{~s}, 1 \mathrm{H}) 8.84(\mathrm{br} \mathrm{s}, 1 \mathrm{H}) 8.73$ (br s, $1 \mathrm{H}) 8.37(\mathrm{~d}, \mathrm{~J}=8.7 \mathrm{~Hz}, 1 \mathrm{H}) 8.29(\mathrm{~d}, \mathrm{~J}=1.7 \mathrm{~Hz}, 1 \mathrm{H}) 8.16(\mathrm{~d}, \mathrm{~J}=8.7 \mathrm{~Hz}, 1 \mathrm{H}) 7.99(\mathrm{dt}, \mathrm{J}=7.6 \mathrm{~Hz}, 1 \mathrm{H}) 7.88(\mathrm{br}$ s, $1 \mathrm{H}) 7.73(\mathrm{t}, \mathrm{J}=7.6 \mathrm{~Hz}, 1 \mathrm{H}) 7.68(\mathrm{dt}, \mathrm{J}=7.7 \mathrm{~Hz}, 1 \mathrm{H}) 4.04(\mathrm{~s}, 3 \mathrm{H}) 3.64-3.44(\mathrm{~m}, 8 \mathrm{H}) 1.98(\mathrm{br} \mathrm{s}, 3 \mathrm{H}) .{ }^{13} \mathrm{C}-$ NMR (500 MHz, DMSO-d $\left.)_{6}\right) \delta 168.6(1 \mathrm{C}), 167.0$ (1C), 163.1(1C), 154.6(1C), 150.2(1C), 150.0(1C), 142.6(1C), 136.6(1C), 136.2(1C), 134.9(1C), 133.2(1C), 131.3(1C), 129.3(1C), 129.1(1C), 128.8(1C), 128.5(1C), 128.4(1C), 124.2(1C), 122.4(1C), 115.1(1C), 95.9(1C), 61.3(1C), 54.8(1C), 47.0(2C), 45.3(2C), 21.2(1C). UPLC/MS Method 2: $0.86 \mathrm{~min}, 493.3[\mathrm{M}+\mathrm{H}]^{+}$. HRMS (ESI $)$calcd for $\mathrm{C}_{28} \mathrm{H}_{25} \mathrm{~N}_{6} \mathrm{O}_{3}$ $[\mathrm{M}+\mathrm{H}]^{+}$493.19827, $\mathrm{C}_{28} \mathrm{H}_{24} \mathrm{NaN}_{6} \mathrm{O}_{3}[\mathrm{M}+\mathrm{Na}]^{+}$515.18021, found 493.19818, 515.18018.

\section{Synthetic sequence towards compound $6 f$.}
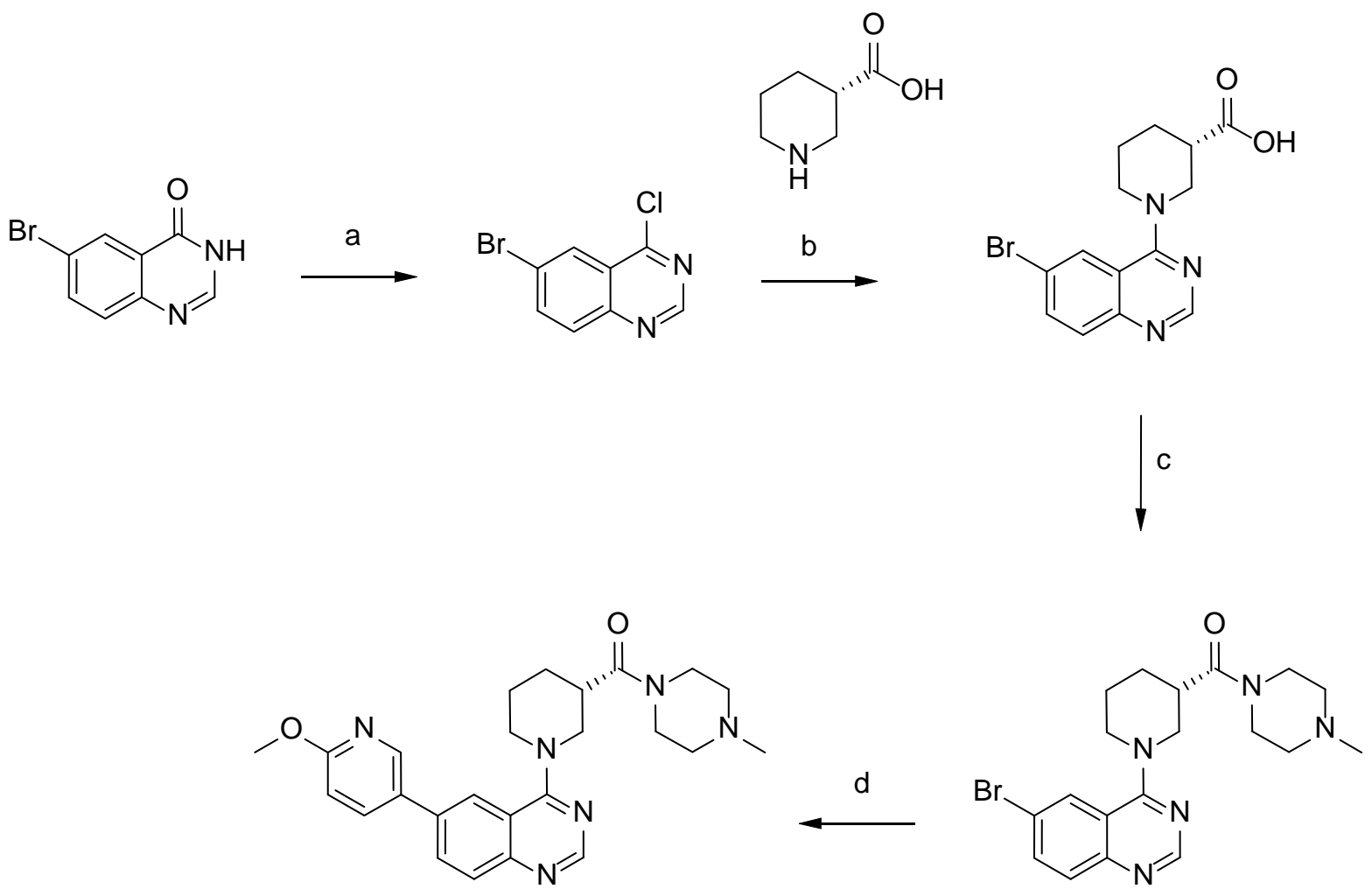

Supplementary Scheme 2: Synthetic sequence towards compound 6f. Reagents and conditions: a) $\mathrm{POCl}_{3}$, $140^{\circ} \mathrm{C}$; b) triethylamine, 2-propanol, rt; c) 1-methylpiperazine, HBTU, DIPEA, DCM, rt; e) (6methoxypyridin-3-yl)boronic acid, $\mathrm{Pd}\left(\mathrm{PPh}_{3}\right)_{4}, 1 \mathrm{M}$ aqueous $\mathrm{Na}_{2} \mathrm{CO}_{3}, \mathrm{DME}, 140^{\circ} \mathrm{C}$. 
(S)-1-(6-bromoquinazolin-4-yl)piperidine-3-carboxylic acid<smiles>O=C(O)[C@H]1CCCN(c2ncnc3ccc(Br)cc23)C1</smiles>

(S)-piperidine-3-carboxylic acid $(0.80 \mathrm{~g}, 6.16 \mathrm{mmol})$ and trimethylamine $(1.72 \mathrm{ml}, 12.3 \mathrm{mmol})$ were added to a solution of 6-bromo-4-chloroquinazoline $(1.0 \mathrm{~g}, 4.11 \mathrm{mmol})$ in 2-propanol $(15 \mathrm{ml})$, and the resulting mixture was stirred for $30 \mathrm{~min}$ at $\mathrm{rt}$. After that time, the reaction mixture was diluted with water and acidified to $\mathrm{pH}=4$ with an aqueous $\mathrm{HCl}$ solution $(1 \mathrm{M})$. The precipitated solid was filtered off and dried under reduce pressure to yield the title compound $(1.29 \mathrm{~g}, 3.84 \mathrm{mmol}, 93 \%) .{ }^{1} \mathrm{H}$ NMR $\left(400 \mathrm{MHz}, \mathrm{DMSO}-d_{6}\right) \delta$ $8.65(\mathrm{~s}, 1 \mathrm{H}), 8.20(\mathrm{~d}, 1 \mathrm{H}), 7.95(\mathrm{dd}, 1 \mathrm{H}), 7.75(\mathrm{~d}, 1 \mathrm{H}), 4.25-4.20(\mathrm{~m}, 1 \mathrm{H}), 4.00-3.85(\mathrm{~m}, 1 \mathrm{H}), 3.55-3.35$ $(\mathrm{m}, 2 \mathrm{H}), 2.80-2.65(\mathrm{~m}, 1 \mathrm{H}), 2.05-1.95(\mathrm{~m}, 1 \mathrm{H}), 1.90-1.60(\mathrm{~m}, 3 \mathrm{H})$. HPLC/MS Method 1: 0.72min, $336.3[\mathrm{M}+\mathrm{H}]^{+}$.

Characterization of compounds $2 \mathrm{a}-\mathrm{d}, 3 \mathrm{~d}, 4 \mathrm{~d}, 5 \mathrm{~d}, 6 \mathrm{~d}, 6 \mathrm{e}, 6 \mathrm{f}, 7,8,9$ and 10

6-(quinoline-3-yl)quinazoline 2a<smiles>c1ccc2ncc(-c3ccc4ncncc4c3)cc2c1</smiles>

${ }^{1} \mathrm{H}$ NMR $\left(400 \mathrm{MHz}, \mathrm{DMSO}_{6}\right) \delta 9.72(\mathrm{~s}, 1 \mathrm{H}), 9.41(\mathrm{~d}, \mathrm{~J}=35.7 \mathrm{~Hz}, 2 \mathrm{H}), 9.05-8.52(\mathrm{~m}, 3 \mathrm{H}), 8.16(\mathrm{dd}, \mathrm{J}=$ 34.1, 7.1 Hz, 3H), 7.94 - $7.62(\mathrm{~m}, 2 \mathrm{H})$. UPLC/MS Method 2: $0.83 \mathrm{~min}, 258.1[\mathrm{M}+\mathrm{H}]^{+}$.

4-phenyl-6-(quinoline-3-yl)quinazoline 2b<smiles>c1ccc(-c2ncnc3ccc(-c4cnc5ccccc5c4)cc23)cc1</smiles>

${ }^{1} \mathrm{H}$ NMR $\left(400 \mathrm{MHz}, \mathrm{CD}_{3} \mathrm{OD}\right) \delta 9.27(\mathrm{~d}, \mathrm{~J}=58.1 \mathrm{~Hz}, 2 \mathrm{H}), 8.69(\mathrm{~s}, 1 \mathrm{H}), 8.57-8.43(\mathrm{~m}, 2 \mathrm{H}), 8.29(\mathrm{~d}, \mathrm{~J}=$ $8.6 \mathrm{~Hz}, 1 \mathrm{H}), 8.08(\mathrm{t}, \mathrm{J}=9.2 \mathrm{~Hz}, 2 \mathrm{H}), 7.97$ - $7.60(\mathrm{~m}, 7 \mathrm{H})$. UPLC/MS Method 2: $1.10 \mathrm{~min}, 334.2[\mathrm{M}+\mathrm{H}]^{+}$.

4-(3,4-dimethoxyphenyl)-6-(quinoline-3-yl)quinazoline 2c 
<smiles>COc1ccc(-c2ncnc3ccc(-c4cnc5ccccc5c4)cc23)cc1OC</smiles>

${ }^{1} \mathrm{H}$ NMR $\left(400 \mathrm{MHz}, \mathrm{DMSO}_{-} \mathrm{d}_{6}\right) \delta 9.35(\mathrm{~d}, \mathrm{~J}=13.3 \mathrm{~Hz}, 2 \mathrm{H}), 8.78(\mathrm{~s}, 1 \mathrm{H}), 8.73-8.49$ (m, 2H), $8.32-8.03$ $(\mathrm{m}, 3 \mathrm{H}), 7.88-7.48(\mathrm{~m}, 4 \mathrm{H}), 7.22(\mathrm{~d}, \mathrm{~J}=8.2 \mathrm{~Hz}, 1 \mathrm{H}), 3.89(\mathrm{~d}, \mathrm{~J}=5.1 \mathrm{~Hz}, 6 \mathrm{H})$. UPLC/MS Method 2: 1.04 $\min , 394.2[\mathrm{M}+\mathrm{H}]^{+}$.

(4-methylpiperazin-1-yl)(3-(6-(quinoline-3-yl)quinazolin-4-yl)phenyl)methanone 2d<smiles>CN1CCN(C(=O)c2cccc(-c3ncnc4ccc(-c5cnc6ccccc6c5)cc34)c2)CC1</smiles>

${ }^{1} \mathrm{H}$ NMR $\left(400 \mathrm{MHz}, \mathrm{DMSO}_{6}\right) \delta 9.44(\mathrm{~s}, 1 \mathrm{H}), 9.33(\mathrm{~d}, \mathrm{~J}=2.2 \mathrm{~Hz}, 1 \mathrm{H}), 8.81(\mathrm{~d}, \mathrm{~J}=1.9 \mathrm{~Hz}, 1 \mathrm{H}), 8.60(\mathrm{~d}, \mathrm{~J}$ $=8.9 \mathrm{~Hz}, 1 \mathrm{H}), 8.49(\mathrm{~s}, 1 \mathrm{H}), 8.31(\mathrm{~d}, \mathrm{~J}=8.7 \mathrm{~Hz}, 1 \mathrm{H}), 8.07(\mathrm{dd}, \mathrm{J}=15.0,8.3 \mathrm{~Hz}, 3 \mathrm{H}), 7.88(\mathrm{~s}, 1 \mathrm{H}), 7.82(\mathrm{t}, \mathrm{J}$ $=7.7 \mathrm{~Hz}, 1 \mathrm{H}), 7.76(\mathrm{t}, \mathrm{J}=7.7 \mathrm{~Hz}, 1 \mathrm{H}), 7.73-7.63(\mathrm{~m}, 2 \mathrm{H}), 3.51(\mathrm{~m}, 4 \mathrm{H}), 2.20(\mathrm{~m}, 4 \mathrm{H}), 1.99(\mathrm{~s}, 3 \mathrm{H})$. UPLC/MS Method 2: $0.69 \mathrm{~min}, 460.3[\mathrm{M}+\mathrm{H}]^{+}$.

(3-(6-(3,4-dimethoxyphenyl)quinazolin-4-yl)phenyl)(4-methylpiperazin-1-yl)methanone 3d<smiles>COc1ccc(-c2ccc3ncnc(-c4cccc(C(=O)N5CCN(C)CC5)c4)c3c2)cc1OC</smiles>

${ }^{1} \mathrm{H}$ NMR (400 MHz, DMSO-d $\left.)_{6}\right) \oint .36(\mathrm{~s}, 1 \mathrm{H}), 8.40(\mathrm{dd}, J=8.8,2.0 \mathrm{~Hz}, 1 \mathrm{H}), 8.21-8.16(\mathrm{~m}, 2 \mathrm{H}), 8.01$ $(\mathrm{dt}, J=7.7,1.3 \mathrm{~Hz}, 1 \mathrm{H}), 7.86(\mathrm{~s}, 1 \mathrm{H}), 7.74(\mathrm{t}, J=7.7 \mathrm{~Hz}, 1 \mathrm{H}), 7.66(\mathrm{dt}, J=7.6,1.3 \mathrm{~Hz}, 1 \mathrm{H}), 7.32(\mathrm{~d}, J=$ $2.1 \mathrm{~Hz}, 1 \mathrm{H}), 7.27$ (dd, J = 8.3, 2.1 Hz, 1H), 7.08 (d, J = 8.4 Hz, 1H), $3.86(\mathrm{~s}, 3 \mathrm{H}), 3.81(\mathrm{~s}, 3 \mathrm{H}), 3.69-3.39$ (m, 4H), $2.45-2.09(\mathrm{~m}, 7 \mathrm{H})$. UPLC/MS Method 2: $0.70 \mathrm{~min}, 469.3[\mathrm{M}+\mathrm{H}]^{+}$. 
2-methoxy-5-(4-(3-(4-methylpiperazine-1-carbonyl)phenyl)quinazolin-6-yl)nicotinonitrile 4d<smiles>COc1ncc(-c2ccc3ncnc(-c4cccc(C(=O)N5CCN(C)CC5)c4)c3c2)cc1C#N</smiles>

${ }^{1} \mathrm{H}$ NMR (400 MHz, DMSO-d $) \delta 9.41$ (s, 1H), 8.90 (d, 1H), 8.79 (d, 1H), 8.43 (dd, $\left.1 \mathrm{H}\right), 8.34(\mathrm{~d}, 1 \mathrm{H})$, $8.23(\mathrm{~d}, 1 \mathrm{H}), 8.01(\mathrm{dt}, 1 \mathrm{H}), 7.83$ (br s, $1 \mathrm{H}), 7.74(\mathrm{t}, 1 \mathrm{H}), 7.65$ (dt, 1H), 4.07 (s, 3H), 3.62 (br s, $2 \mathrm{H}), 3.46$ (br s, 2H), 2.35 (br s, 2H), 2.22 (br s, 2H), 2.15(s, 3H). HPLC/MS Method 1: 0.94 min, $465.1[\mathrm{M}+\mathrm{H}]^{+}$.

(3-(6-(6-methoxy-5-(trifluoromethyl)pyridin-3-yl)quinazolin-4-yl)phenyl)(4-methylpiperazin-1-yl)methanone $5 \mathrm{~d}$<smiles>COc1ncc(-c2ccc3ncnc(-c4cccc(C(=O)N5CCN(C)CC5)c4)c3c2)cc1C(F)(F)F</smiles>

${ }^{1} \mathrm{H}$ NMR $\left(400 \mathrm{MHz}, \mathrm{DMSO}_{6}\right) \delta 9.41(\mathrm{~s}, 1 \mathrm{H}), 8.87(\mathrm{~d}, \mathrm{~J}=2.1 \mathrm{~Hz}, 1 \mathrm{H}), 8.52-8.19(\mathrm{~m}, 4 \mathrm{H}), 8.03(\mathrm{~d}, \mathrm{~J}=$ $7.6 \mathrm{~Hz}, 1 \mathrm{H}), 7.86(\mathrm{~s}, 1 \mathrm{H}), 7.77-7.59(\mathrm{~m}, 2 \mathrm{H}), 4.06(\mathrm{~s}, 3 \mathrm{H}), 3.71-3.35(\mathrm{~m}, 4 \mathrm{H}), 2.40-2.10(\mathrm{~m}, 7 \mathrm{H})$. UPLC/MS Method 2: $0.82 \mathrm{~min}, 508.3[\mathrm{M}+\mathrm{H}]^{+}$.

(3-(6-(6-methoxypyridin-3-yl)quinazolin-4-yl)phenyl)(4-methylpiperazin-1-yl)methanone 6d<smiles>COc1ccc(-c2ccc3ncnc(-c4cccc(C(=O)N5CCN(C)CC5)c4)c3c2)cn1</smiles>

${ }^{1} \mathrm{H}$ NMR $\left(400 \mathrm{MHz}, \mathrm{DMSO}-\mathrm{d}_{6}\right) \delta 9.38(\mathrm{~s}, 1 \mathrm{H}), 8.59(\mathrm{~d}, J=2.3 \mathrm{~Hz}, 1 \mathrm{H}), 8.39(\mathrm{dd}, J=8.8,2.1 \mathrm{~Hz}, 1 \mathrm{H})$, $8.25-8.18(\mathrm{~m}, 2 \mathrm{H}), 8.12(\mathrm{dd}, J=8.6,2.6 \mathrm{~Hz}, 1 \mathrm{H}), 8.00(\mathrm{dt}, J=7.7,1.3 \mathrm{~Hz}, 1 \mathrm{H}), 7.84(\mathrm{t}, J=1.4 \mathrm{~Hz}, 1 \mathrm{H})$, $7.74(\mathrm{t}, J=7.7 \mathrm{~Hz}, 1 \mathrm{H}), 7.65(\mathrm{dt}, J=7.7,1.3 \mathrm{~Hz}, 1 \mathrm{H}), 6.96(\mathrm{~d}, J=8.6 \mathrm{~Hz}, 1 \mathrm{H}), 3.92(\mathrm{~s}, 3 \mathrm{H}), 3.75-3.33$ $(\mathrm{m}, 4 \mathrm{H}), 2.41-2.17(\mathrm{~m}, 4 \mathrm{H}), 2.15(\mathrm{~s}, 3 \mathrm{H})$. UPLC/MS Method 2: $0.69 \mathrm{~min}, 440.2[\mathrm{M}+\mathrm{H}]^{+}$. 
(5-(6-(6-methoxypyridin-3-yl)quinazolin-4-yl)pyridin-3-yl)(4-methylpiperazin-1-yl)methanone 6e<smiles>COc1ccc(-c2ccc3ncnc(-c4cncc(C(=O)N5CCN(C)CC5)c4)c3c2)cn1</smiles>

${ }^{1} \mathrm{H}$ NMR $\left(400 \mathrm{MHz}, \mathrm{DMSO}_{6}\right) \delta 9.43(\mathrm{~s}, 1 \mathrm{H}), 9.14(\mathrm{~d}, J=2.1 \mathrm{~Hz}, 1 \mathrm{H}), 8.84(\mathrm{~d}, J=2.0 \mathrm{~Hz}, 1 \mathrm{H}), 8.67$ $8.61(\mathrm{~m}, 1 \mathrm{H}), 8.43(\mathrm{dd}, J=8.8,2.1 \mathrm{~Hz}, 1 \mathrm{H}), 8.32(\mathrm{t}, J=2.1 \mathrm{~Hz}, 1 \mathrm{H}), 8.28-8.21(\mathrm{~m}, 2 \mathrm{H}), 8.17(\mathrm{dd}, J=$ 8.7, $2.6 \mathrm{~Hz}, 1 \mathrm{H}), 7.07-6.88(\mathrm{~m}, 1 \mathrm{H}), 3.92(\mathrm{~s}, 3 \mathrm{H}), 3.73-3.37(\mathrm{~m}, 4 \mathrm{H}), 2.42-2.20(\mathrm{~m}, 4 \mathrm{H}), 2.17(\mathrm{~s}, 3 \mathrm{H})$. UPLC/MS Method 2: $0.61 \mathrm{~min}, 441.2[\mathrm{M}+\mathrm{H}]^{+}$.

(s)-(1-(6-(6-methoxypyridin-3-yl)quinazolin-4-yl)piperidin-3-yl)(4-methylpiperazin-1-yl)methanone $6 f$<smiles>COc1ccc(-c2ccc3ncnc(N4CCC[C@@H](C(=O)N5CCN(C)CC5)C4)c3c2)cn1</smiles>

${ }^{1} \mathrm{H}$ NMR $\left(400 \mathrm{MHz}, \mathrm{DMSO}_{6}\right) \delta 8.69-8.52(\mathrm{~m}, 2 \mathrm{H}), 8.18-8.07(\mathrm{~m}, 3 \mathrm{H}), 7.88(\mathrm{~d}, \mathrm{~J}=9.3 \mathrm{~Hz}, 1 \mathrm{H}), 6.97$ $(\mathrm{d}, J=8.6 \mathrm{~Hz}, 1 \mathrm{H}), 4.43-4.23(\mathrm{~m}, 2 \mathrm{H}), 3.93(\mathrm{~s}, 3 \mathrm{H}), 3.72-3.61(\mathrm{~m}, 1 \mathrm{H}), 3.60-3.49(\mathrm{~m}, 2 \mathrm{H}), 3.36-3.29$ $(\mathrm{m}, 3 \mathrm{H}), 3.29-3.20(\mathrm{~m}, 1 \mathrm{H}), 3.20-3.07(\mathrm{~m}, 1 \mathrm{H}), 2.39-2.07(\mathrm{~m}, 7 \mathrm{H}), 1.96-1.84(\mathrm{~m}, 1 \mathrm{H}), 1.82-1.61$ (m, 3H). UPLC/MS Method 2: $0.53 \mathrm{~min}, 447.3[\mathrm{M}+\mathrm{H}]^{+}$.

1-(4-(3-(6-(quinolin-3-yl)quinazolin-4-yl)benzoyl)piperazin-1-yl)ethan-1-one 7<smiles>CC(=O)N1CCN(C(=O)c2cccc(-c3ncnc4ccc(-c5cnc6ccccc6c5)cc34)c2)CC1</smiles>

${ }^{1} \mathrm{H}$ NMR $(400 \mathrm{MHz}$, DMSO-d $) \delta 9.44(\mathrm{~s}, 1 \mathrm{H}), 9.35$ (d, $\left.J=1.9 \mathrm{~Hz}, 1 \mathrm{H}\right), 8.83(\mathrm{~s}, 1 \mathrm{H}), 8.62(\mathrm{dd}, J=8.8,2.0$ $\mathrm{Hz}, 1 \mathrm{H}), 8.51(\mathrm{~d}, J=1.7 \mathrm{~Hz}, 1 \mathrm{H}), 8.31(\mathrm{~d}, J=8.8 \mathrm{~Hz}, 1 \mathrm{H}), 8.13-8.03(\mathrm{~m}, 3 \mathrm{H}), 7.97$ (s, $1 \mathrm{H}), 7.86-7.65$ (m, 4H), $3.77-3.39(\mathrm{~m}, 8 \mathrm{H}), 1.91(\mathrm{~d}, \mathrm{~J}=90.5 \mathrm{~Hz}, 3 \mathrm{H})$. UPLC/MS Method 2: $0.84 \mathrm{~min}, 488.3[\mathrm{M}+\mathrm{H}]^{+}$. 
1-(4-(3-(6-(3,4-dimethoxyphenyl)quinazolin-4-yl)benzoyl)piperazin-1-yl)ethan-1-one 8<smiles>COc1ccc(-c2ccc3ncnc(-c4cccc(C(=O)N5CCN(C(C)=O)CC5)c4)c3c2)cc1OC</smiles>

${ }^{1} \mathrm{H}$ NMR (400 MHz, DMSO-d $) \delta 9.37(\mathrm{~s}, 1 \mathrm{H}), 8.42(\mathrm{dd}, J=8.8,2.0 \mathrm{~Hz}, 1 \mathrm{H}), 8.27-8.13(\mathrm{~m}, 2 \mathrm{H}), 8.01(\mathrm{~d}$, $J=7.6 \mathrm{~Hz}, 1 \mathrm{H}), 7.93(\mathrm{~s}, 1 \mathrm{H}), 7.83-7.64(\mathrm{~m}, 2 \mathrm{H}), 7.34(\mathrm{~d}, J=2.1 \mathrm{~Hz}, 1 \mathrm{H}), 7.30(\mathrm{dd}, J=8.3,2.1 \mathrm{~Hz}, 1 \mathrm{H})$, $7.09(\mathrm{~d}, J=8.4 \mathrm{~Hz}, 1 \mathrm{H}), 3.86(\mathrm{~s}, 3 \mathrm{H}), 3.82(\mathrm{~s}, 3 \mathrm{H}), 3.76-3.36(\mathrm{~m}, 8 \mathrm{H}), 2.00(\mathrm{~s}, 3 \mathrm{H})$. UPLC/MS Method 2: $0.87 \mathrm{~min}, 497.2[\mathrm{M}+\mathrm{H}]^{+}$.

1-(4-(3-(6-(6-methoxypyridin-3-yl)quinazolin-4-yl)benzoyl)piperazin-1-yl)ethan-1-one 9<smiles>COc1ccc(-c2ccc3ncnc(-c4cccc(C(=O)N5CCN(C(C)=O)CC5)c4)c3c2)cn1</smiles>

${ }^{1} \mathrm{H}$ NMR (400 MHz, DMSO-d $\left.)_{6}\right) \delta 9.39(\mathrm{~s}, 1 \mathrm{H}), 8.61(\mathrm{~d}, J=2.3 \mathrm{~Hz}, 1 \mathrm{H}), 8.40(\mathrm{dd}, J=8.8,2.0 \mathrm{~Hz}, 1 \mathrm{H})$, $8.27-8.18(\mathrm{~m}, 2 \mathrm{H}), 8.13(\mathrm{dd}, J=8.6,2.6 \mathrm{~Hz}, 1 \mathrm{H}), 8.01(\mathrm{dt}, J=7.6,1.4 \mathrm{~Hz}, 1 \mathrm{H}), 7.90(\mathrm{~s}, 1 \mathrm{H}), 7.79-7.64$ $(\mathrm{m}, 2 \mathrm{H}), 6.97(\mathrm{~d}, J=8.6 \mathrm{~Hz}, 1 \mathrm{H}), 3.92(\mathrm{~s}, 3 \mathrm{H}), 3.73-3.36(\mathrm{~m}, 8 \mathrm{H}), 2.00(\mathrm{~s}, 3 \mathrm{H})$. UPLC/MS Method 2: $0.82 \mathrm{~min}, 468.2[\mathrm{M}+\mathrm{H}]^{+}$.

1-(4-(3-(6-(6-methoxy-5-(trifluoromethyl)pyridin-3-yl)quinazolin-4-yl)benzoyl)piperazin-1-yl)ethan-1-one 10<smiles>COc1ncc(-c2ccc3ncnc(-c4cccc(C(=O)N5CCN(C(C)=O)CC5)c4)c3c2)cc1C(F)(F)F</smiles>

${ }^{1} \mathrm{H}$ NMR $\left(400 \mathrm{MHz}\right.$, Methanol- $\left.d_{4}\right) \delta 9.36(\mathrm{~s}, 1 \mathrm{H}), 8.74(\mathrm{~s}, 1 \mathrm{H}), 8.43-8.21(\mathrm{~m}, 4 \mathrm{H}), 8,10-7.90(\mathrm{~m}, 2 \mathrm{H}$, 7.80- $7.71(\mathrm{~m}, 2 \mathrm{H}), 4.11(\mathrm{~s}, 3 \mathrm{H}), 4.00-3.50(\mathrm{~m}, 8 \mathrm{H}), 2.14(\mathrm{~s}, 3 \mathrm{H})$. UPLC/MS Method 2: $0.98 \mathrm{~min}, 536.3$ $[\mathrm{M}+\mathrm{H}]^{+}$. 


\section{$\underline{\text { References }}$}

(1) Emsley, P.; Cowtan, K. Coot: Model-Building Tools for Molecular Graphics. Acta Crystallogr. D Biol. Crystallogr. 2004, 60 (12), 2126-2132.

(2) Bricogne, G.; Blanc, E.; Brandl, M.; Flensburg, C.; Keller, P.; Paciorek, W.; Roversi, P.; Sharff, A.; Smart, O. S.; Vonrhein, C.; Womack, T. O. Buster Version 2.8.0; Cambridge, United Kingdom: Global Phasing Ltd., 2011.

(3) Berndt, A.; Miller, S.; Williams, O.; Le, D. D.; Houseman, B. T.; Pacold, J. I.; Gorrec, F.; Hon, W.C.; Liu, Y.; Rommel, C.; Gaillard, P.; Ruckle, T.; Schwarz, M. K.; Shokat, K. M.; Shaw, J. P.; Williams, R. L. The p110 $\delta$ Crystal Structure Uncovers Mechanisms for Selectivity and Potency of Novel PI3K Inhibitors. Nat. Chem. Biol. 2010, 6 (2), 117-124.

(4) Kabsch, W. Automatic Processing of Rotation Diffraction Data from Crystals of Initially Unknown Symmetry and Cell Constants. J. Appl. Crystallogr. 1993, 26 (6), 795-800.

(5) Kroemer, M.; Dreyer, M. K.; Wendt, K. U. APRV - a Program for Automated Data Processing, Refinement and Visualization. Acta Crystallogr. D Biol. Crystallogr. 2004, 60 (9), 1679-1682.

(6) Maier, J. A.; Martinez, C.; Kasavajhala, K.; Wickstrom, L.; Hauser, K. E.; Simmerling, C. ff14SB: Improving the Accuracy of Protein Side Chain and Backbone Parameters from ff99SB. J. Chem. Theory Comput. 2015, 11 (8), 3696-3713.

(7) Wang, J.; Wolf, R. M.; Caldwell, J. W.; Kollman, P. A.; Case, D. A. Development and Testing of a General Amber Force Field. J. Comput. Chem. 2004, 25 (9), 1157-1174.

(8) Jakalian, A.; Bush, B. L.; Jack, D. B.; Bayly, C. I. Fast, Efficient Generation of High-Quality Atomic Charges. AM1-BCC Model: I. Method. J. Comput. Chem. 2000, 21 (2), 132-146.

(9) Case, D. A.; Berryman, J. T.; Betz, R. M.; Cerutti, D. S.; Cheatham, III, T. E.; Darden, T. A.; Duke, R. E.; Giese, T. J.; Gohlke, H.; Goetz, A. W.; Homeyer, N.; Izadi, S.; Janowski, P.; Kaus, J.; Kovalenko, A.; Lee, T. S.; LeGrand, S.; Li, P.; Luchko, T.; Luo, R.; Madej, B.; Merz, K. M.; Monard, G.; Needham, P.; Nguyen, H.; Nguyen, H. T.; Omelyan, I.; Onufriev, A.; Roe, D. R.; Roitberg, A.; Salomon-Ferrer, R.; Simmerling, C. L.; Smith, W.; Swails, J.; Walker, R. C.; Wang, J.; Wolf, R. M.; Wu, X.; York, D. M.; Kollman, P. A. AMBER 2015; University of California, San Francisco, 2015. 